V. 12 N. 1

JAN-ABR 2016

ISSN 2317-6172

Recebido: 25.11 .2014

Aprovado: 15.12 .2015

DOI: http://dx.doi.org/10.1590/ 2317-6172201607

1 Universidade de Brasília Brasília - DF - Brasil

2 Universidade de Brasília Brasília - DF - Brasil

3 Universidade de Brasília Brasília - DF - Brasil

\section{Controle de constitucionalidade no Brasil: eficácia das políticas de concentração e seletividade}

\author{
JUDICIAL REVIEW IN BRAZIL: EFFECTIVENESS OF CENTRALIZATION
}

AND SELECTIVITY POLICIES

\author{
Alexandre Araújo Costa ${ }^{1}$,Alexandre Douglas Zaidan de Carvalho ${ }^{2}$ \\ e Felipe Justino de Farias ${ }^{3}$
}

\section{Resumo}

Comumente, os estudos dedicados à centralização da jurisdição constitucional no Supremo Tribunal Federal (STF) adotam, como fundamento, suposta ampliação da segurança jurídica e presumido ganho de eficácia em contexto de crescente demanda do Poder Judiciário. Comparando-se os discursos nos debates legislativos que alteraram o texto constitucional, expandindo os efeitos das decisões do STF, e os dados levantados pela pesquisa "A quem interessa o controle concentrado de constitucionalidade?", analisou-se, neste artigo, a eficácia do aumento da concentração do controle no STF para a redução da litigiosidade e, consequentemente, da sobrecarga nessa corte. Observou-se que a ampliação dos poderes do STF na adjudicação constitucional, durante os últimos cinquenta anos, não resultou em diminuição da sobrecarga; contudo, as estratégias de seletividade, para reduzir os julgamentos de mérito, foram mais eficazes. Por outro lado, houve a estabilização do número de acórdãos proferidos, fato que refuta o reiterado argumento de inviabilização dos trabalhos do tribunal.

\section{Palavras-chave}

Supremo Tribunal Federal; controle concentrado; evolução histórica; sobrecarga de processos.

\section{Abstract}

Usually, studies about the centralization of the constitutional adjudication in the Brazilian Supreme Court adopt as a premise that an increase in legal certainty will lead to a gain in efficiency, in a context of a growing caseload on the Judicial Branch. In this paper, this premise is analyzed based on the comparative assessment of the speeches in law-making processes that changed the constitutional text and the data collected in the research "Who is Interested in the Concentrated System of Judicial Review?". The article concludes that the increase in the Brazilian Supreme Court's power to adjudicate the Constitution during the last 50 years did not result in the reduction of the excessive caseload. The methods of selection of cases were more efficient, however. At the same time, the amount of the court's decisions has been stable. The paper concludes that this fact refutes the reiterated argument that the operation of the Court tends to be unviable.

\section{Keywords}

Brazilian Supreme Court; concentrated control; historical evolution; excessive caseload. 


\section{INTRODUÇÃO}

Desde que a Emenda Constitucional (EC) 16/1965 atribuiu ao Supremo Tribunal Federal (STF) a competência para julgar Representação de Inconstitucionalidade (Rp), a jurisdição constitucional brasileira tem sido marcada por um gradual processo de concentração decisória nesse Tribunal. Embora o sistema brasileiro continue sendo qualificado como misto, devido à coexistência de elementos de controle difuso e concentrado, é cada vez mais comum o reconhecimento de que "esta convivência não se faz sem uma permanente tensão dialética” (voto min. Sepúlveda Pertence, STF, ADC 1 QO, 1993)² e de que vivemos uma tendência de "ampliação do papel da jurisdição constitucional concentrada e abstrata" (BARROSO, 2009, p. 274).

Ao longo dos cinquenta últimos anos, variadas mudanças constitucionais, legislativas e jurisprudenciais alteraram as estruturas formais do controle de constitucionalidade. Quase sempre, foram movidas pelo discurso de que era preciso enfrentar a crise decorrente da sobrecarga no Poder Judiciário, uma vez que havia um número de ações e recursos superior a sua capacidade de processamento. Tais alterações foram implementadas em nome da garantia de eficiência e racionalização, sendo que as estratégias voltadas a evitar o "estrangulamento da máquina judiciária” (voto min. Sepúlveda Pertence, STF, ADC 1 QO, 1993) envolveram recorrentemente uma combinação de concentração e de seletividade. Concentração no sentido de que as mudanças legislativas e jurisprudenciais desde 1965 atribuíram ao STF poderes cada vez mais amplos, de modo que menos decisões pudessem solucionar mais processos. E seletividade no sentido de que foram criadas várias possibilidades para limitar o acesso ao controle de constitucionalidade, permitindo assim uma redução nos processos cujo mérito deveria ser apreciado pelo Tribunal.

O dúplice processo de concentração e seletividade continua em curso, embora não tenha logrado solucionar o problema da sobrecarga, que continua sendo indicada, principalmente por juízes, como uma das falhas do Poder Judiciário brasileiro. As propostas atuais de mudança apontam para um acirramento desse processo, como mostram recentes entrevistas dos ministros do STF publicadas em artigo na revista Consultor Jurídico, em 2014. No que se refere à concentração, Marco Aurélio considera que o futuro do STF é ser uma “corte essencialmente constitucional” (DIANTE POSSIBILIDADE.., 2014), entendendo que no Brasil deveria haver apenas o controle concentrado, exercido somente pelo STF.

1 Ao longo deste trabalho, toda norma jurídica citada que não contar com referência específica encontra-se disponível no Portal da Legislação do governo federal, disponível em: <http://www4.planalto.gov.br/legislacao $>$.

2 Todos os julgados do STF citados estão disponíveis na página de Acompanhamento Processual do Supremo (disponível em: <http://www.stf.jus.br/portal/processo/pesquisarProcesso.asp>). O modelo de citação adotado indica o autor do trecho citado (quando houver), seguido pelo nome do Tribunal, pela classe e número do processo referido e pelo ano de julgamento. 
Por seu turno, Luís Barroso defende a ampliação da concentração para a jurisdição não constitucional, transformando "toda decisão do STF em vinculante, e não só as tomadas em controle de constitucionalidade" (DIANTE POSSIBILIDADE..., 2014). Quanto à seletividade, Luís Barroso "defende que haja filtros de recursos mais radicais" e sugere "que o $\mathrm{Su}$ premo defina a cada início de ano ou de semestre quantas repercussões gerais devem ser reconhecidas" (DIANTE POSSIBILIDADE..., 2014). E Teori Zavascki, embora reconheça que o aumento da seletividade resulte em que certas decisões equivocadas não sejam corrigidas, considera que "filtrar mais trará o prejuízo menor" porque essa estratégia permitiria que os tribunais superiores julgassem “as questões realmente importantes" (DIANTE POSSIBILIDADE..., 2014).

Apesar de continuarem sendo os instrumentos predominantes de gestão da litigiosidade na jurisdição constitucional, as estratégias de concentração e seletividade enfrentaram obstáculos em cada momento de mudança, especialmente porque elas se opõem a alguns princípios arraigados do nosso sistema jurídico. De um lado, a construção de filtros judiciais muitas vezes é compreendida como uma violação do princípio constitucional da universalidade do acesso ao Judiciário. De outro, modelos concentrados de jurisdição constitucional exigem decisões com efeito vinculante, o que sempre causou tensões com nossa tradição civilista, em que o Poder Judiciário lidava basicamente com questões privadas e seus provimentos tinham efeitos interpartes. Contrapondo-se à tradição jurídica brasileira, todo movimento de centralização decisória implicou maior vinculatividade das decisões do controle concentrado, sendo que o equilíbrio encontrado em cada momento histórico tendia a restringir essa capacidade vinculante, harmonizando-a com o sistema de Civil Law. Ao longo do tempo, contudo, essas resistências foram cedendo e as decisões em controle concentrado conquistaram efeitos cada vez mais amplos.

É relevante observar que foram principalmente mudanças jurisprudenciais que incrementaram os efeitos dos julgamentos no âmbito do controle concentrado. Originalmente, as decisões tinham teor meramente declaratório, em uma sistemática na qual os efeitos constitutivos adviriam apenas do ato do Senado que suspendia a execução da norma julgada inconstitucional. Em 1977, o STF decidiu que as comunicações ao Senado seriam restritas às declarações proferidas incidenter tantum, consolidando entendimento de que as decisões de controle abstrato tinham efeitos erga omnes (MENDES, 1999). Em 2007, um voto do ministro Gilmar Mendes na Reclamação ( $\mathrm{Rcl}$ ) 4335, posteriormente acompanhado pelo ministro Eros Grau, defendeu-se a complementação dessa redução jurisprudencial do papel do Poder Legislativo no controle de constitucionalidade, pelo reconhecimento de que todas as decisões de controle difuso teriam efeitos erga omnes, sem a necessidade de qualquer provimento do Senado. Não obstante essa posição ter sido rejeitada pelos demais ministros, a decisão final da Rcl 4335, ocorrida em 2014, reconheceu que a introdução das súmulas vinculantes pela EC 45/2004 possibilitou que o Tribunal, sem precisar de qualquer participação do Senado, conferisse "eficácia contra todos e efeito vinculante a um entendimento sufragado por este 
Tribunal no julgamento de um processo de índole subjetiva” (voto min. Ricardo Lewandowski, STF, Rcl 4335, 2014).

Além das mudanças jurisprudenciais, os efeitos foram ampliados por alterações legislativas. Em 1993, foi introduzida a Ação Direta de Constitucionalidade (ADC) com efeito vinculante e, em 1999, a legislação conferiu ao STF o direito de modular o efeito ex tunc das declarações de inconstitucionalidade, possibilidade essa que foi jurisprudencialmente estendida ao controle difuso em 2002 (STF, RE 197.917). Por fim, também em 1999, o legislador incluiu a previsão de extensão do efeito vinculante para as Ações Direitas de Inconstitucionalidade (ADIs), consolidando o entendimento jurisprudencial de que o caráter abstrato das ações diretas conferia efeito vinculante a suas decisões (STF, Rcl 621, 1996).

O processo de aumento dos efeitos do controle concentrado também ocorreu no âmbito das possibilidades hermenêuticas à disposição do STF. Ele foi acentuado com a consolidação do instituto da "interpretação conforme", que ocorreu pela primeira vez em ementas do Supremo em 1987 (STF, Rp 1417) e consolidou-se ao longo da década de 1990², quando as referências jurisprudenciais passaram a ser constantes, tendo sido inclusive reconhecido legislativamente pelo art. 28 da Lei n. 9868/1999. Essa estratégia interpretativa conferiu ao STF a possibilidade de editar sentenças interpretativas de constitucionalidade que, como bem acentua Leo Brust (2009), corrigem ou estendem a obra do legislador sem alterar o então predominante discurso do legislador negativo. Outros marcos importantes desse processo foram a reforma do Judiciário realizada pela EC 45/2004, que instituiu as súmulas vinculantes, e a mudança jurisprudencial que, no julgamento do Mandado de Injunção (MI) 670/ES, em 2007, adotou maior ativismo no tratamento da inconstitucionalidade por omissão.

As mudanças procedimentais no controle concentrado e suas consequências não são uma novidade no ordenamento jurídico brasileiro. Faz mais de cinquenta anos que o discurso de concentração e seletividade organiza as iniciativas políticas que se fizeram refletir no modo de compreensão da função da jurisdição constitucional e do papel do STF no arranjo das instituições incumbidas de interpretar a Constituição. Apesar disso, é comum que tal movimento não seja apresentado como parte de um processo de longo prazo, e sim como "uma tendência que se tem manifestado nos últimos anos" (BARROSO, 2009, p. 274).

Torna-se cada vez mais usual uma naturalização do discurso de que o Poder Judiciário funciona tanto melhor quanto mais abstratos forem os seus pronunciamentos, pois esse tipo de estratégia permite responder a muitos processos com uma única decisão. A adoção acrítica desse imperativo de eficiência conduz a discursos que não apresentam a concentração da jurisdição constitucional como uma opção política entre outras, mas que afirmam ser "inevitável o reforço do sistema concentrado” (voto min. Sepúlveda Pertence, STF, ADC 1, 1993).

3 Também a "declaração parcial de inconstitucionalidade sem redução de texto" ocorria na jurisprudência do STF dessa época, como na ADI 491 MC (1991) e na ADI 1.089 (1996). 
A constante afirmação da inevitabilidade da jurisdição constitucional concentrada é normalmente calcada na crença de que esse é um modelo mais eficiente e que, por isso, os instrumentos de concentração e abstração representam estratégias adequadas para enfrentar o fantasma da inviabilidade que tem assombrado o STF desde a década de 1940. Essa crença tem um caráter dogmático, pois se acredita tanto que a concentração teria por resultado lógico maior efetividade que não se considera necessário evidenciar a existência de uma correlação empírica entre concentração e eficiência.

Uma análise mais refinada da correlação entre concentração e eficiência dependeria da observação de informações que não estão disponíveis nas bases de dados atuais e cujo levantamento demandaria um esforço gigantesco. Nada obstante, uma análise cuidadosa de algumas das informações disponíveis (totais anuais de processos ajuizados, distribuídos e julgados, bem como de acórdãos publicados) permite fazer inferências que colocam em dúvida o grau de eficiência das medidas de concentração decisória.

A pesquisa envolvida no presente artigo volta-se a examinar como as vertentes do movimento de concentração e seletividade do controle de constitucionalidade no STF podem ser avaliadas não apenas como uma consequência metodológica de racionalização da atividade judicial, mas também, sobretudo, como uma construção histórica. Nesse movimento, a influência de fatores políticos levanta dúvidas sobre a crença naturalizada na racionalidade e na eficácia do controle concentrado.

Para realizar esse trabalho, fizemos, inicialmente, um mapeamento das alterações legislativas e jurisprudenciais que expandiram a jurisdição do STF. Esse levantamento vai desde a adoção do primeiro instrumento processual de objeção a lei ou ato normativo por via direta (a representação de inconstitucionalidade, introduzida pela EC 16/1965), até a reforma do Judiciário promovida pela EC 45/2004. Com base nesse histórico, realizamos um confronto entre os discursos que organizaram a implementação das alterações no sistema de controle de constitucionalidade e as mudanças efetivas no perfil de litigiosidade, identificadas pelos dados empíricos que mostram a evolução no tempo do volume de processos ajuizados e processos julgados.

O cotejo entre esses diversos elementos indica que as várias estratégias de concentração aparentemente não tiveram um impacto relevante nos padrões de ajuizamento e julgamento. A ausência de informações completas impede uma conclusão definitiva, mas a análise das informações existentes permite indicar que a pressuposição naturalizada de que a concentração gera eficiência deveria ser substituída pela necessidade de que os defensores de uma jurisdição concentrada apresentassem estudos sólidos, para justificar a implementação dessas medidas.

As análises indicam, por outro lado, que tiveram grande impacto as medidas legislativas e jurisprudenciais que introduziram elementos de seletividade, limitando o acesso à jurisdição constitucional, especialmente no âmbito do controle difuso. Assim, as informações demonstram que, apesar de os discursos de fundamentação das sucessivas reformas terem sido sempre 
semelhantes, não há elementos que indiquem que o aumento da concentração foi adequado para o enfrentamento do fantasma da inviabilidade, seja melhorando a eficiência do tribunal, seja diminuindo o número de processos ajuizados.

\section{i A Emenda Constitucional i6/ig65 E O Discurso da SOBReCARga Judicial}

O primeiro instrumento processual hábil a provocar o STF a manifestar-se sobre a constitucionalidade de uma norma jurídica, independentemente de um contexto concreto específico, foi a Rp criada pela EC 16/1965, que se seguiu à edição do Ato Institucional 2, de 27 de outubro de 1965 (AI-2). A dupla introdução legislativa do controle abstrato e do concentrado foi realizada mediante uma modificação no art. 101, I, alínea $k$, da Constituição Federal (CF) de 1946, acrescentando entre as competências originárias do STF o julgamento da "representação contra inconstitucionalidade de lei ou ato de natureza normativa, federal ou estadual, encaminhada pelo Procurador-Geral da República". Além disso, foi facultado ao legislador estadual instituir processo de competência originária dos tribunais de justiça para a declaração de inconstitucionalidade de leis estaduais ou municipais em conflito com a constituição do estado-membro, o que impedia que as constituições estaduais repetissem a estrutura do controle concentrado no nível estadual, tomando como parâmetro a própria $\mathrm{CF}$.

A alteração se deu no contexto da reforma judiciária promovida pelo AI-2, editado pelo "Presidente da República, na condição de Chefe do Governo revolucionário e comandante supremo das forças armadas" e que se autodescrevia como uma norma que "[m]antém a Constituição Federal de 1946, as Constituições Estaduais e respectivas Emendas, com as alterações introduzidas pelo Poder Constituinte originário da Revolução de 31.03.1964” (AI-2, epígrafe). O regime militar fez uma peculiar utilização da ideia de poder constituinte, iniciada pela edição do Ato Institucional de 1964 (AI-1), em que afirmava que "a revolução vitoriosa se investe no exercício do Poder Constituinte”, poder este que não era de titularidade do povo, mas apenas inspirado pelo povo, e tampouco se exauria com o estabelecimento da Constituição.

A existência de um governo soberano, dotado de poder constituinte permanente, impede que se possa falar propriamente da existência de uma constituição ao longo da ditadura militar, pois não é possível considerar supremo um texto constitucional que poderia ser alterado a qualquer tempo pelo governo (COSTA, 2011). Nesse contexto, a ideia de controle de constitucionalidade deve ser percebida com os devidos cuidados, especialmente porque o art. 19 do AI-2 excluía expressamente da apreciação judicial os atos praticados pelo "Comando Supremo da Revolução e pelo Governo Federal” com base no AI-1, assim como os atos de cassação de mandato ou impedimento de parlamentares, governadores e prefeitos praticados até então. 
Nesse contexto de concentração de poderes no Executivo e de intervenção na atividade judicial, realizada especialmente pela ampliação do STF para dezesseis ministros (AI-2, art. $6^{\circ}$ ), não causa espanto que o Projeto de Emenda Constitucional (PEC) 6/1965 (proposta que deu origem à EC 16/1965), apresentado pelo Poder Executivo apenas dez dias depois da edição do AI-2, tenha estabelecido um mecanismo de controle centralizado que somente poderia ser mobilizado pela autoridade indicada ad nutum pelo presidente para atuar como chefe da advocacia pública federal: o procurador-geral da República. Cabe ressaltar que a discussão parlamentar sobre esse projeto ficou claramente prejudicada por ela ter seguido o processo definido pelo art. 21 do AI-2, que fixou em 30 dias o prazo para apreciação de emendas encaminhadas pelo presidente da República e estabeleceu que essa deliberação ocorreria por maioria absoluta, e não pela típica maioria qualificada. De fato, a aprovação da PEC 6/1965 pela Comissão Mista do Congresso aconteceu em 16 de novembro de 1965, ou seja, apenas doze dias após o envio da mensagem presidencial, e a única alteração de relevo foi a rejeição do seu art. 21, que conferia efeitos erga omnes às decisões do STF em controle difuso de constitucionalidade.

A exposição de motivos apresentada pelo ministro da Justiça Juracy Magalhães no encaminhamento do PEC 6/1965 indicava que o projeto tinha por base o trabalho de uma comissão nomeada no governo Castello Branco para estudar propostas de alteração na estrutura da justiça propostas por várias entidades, inclusive o STF, o Tribunal Federal de Recursos (TFR) e a Ordem dos Advogados do Brasil (OAB) (BRASIL, 1965, p. 801). A comissão, relatada por Prado Kelly (que foi nomeado para o STF na data da aprovação do PEC, em uma das vagas criadas pelo AI-2) e composta também por Orosimbo Nonato e Dario de Almeida Magalhães, apresentou propostas voltadas "a debelar, senão pelo menos a minorar, as causas principais da chamada crise das pautas de julgamento, caracterizada pelo acúmulo dos processos a exigir decisão dos tribunais superiores" (BRASIL, 1965, p. 801). Cabe ressaltar que esse trabalho já havia sido utilizado como base para alterações implantadas pelo AI-2, inclusive oferecendo uma justificativa "técnica" para a célebre elevação do número de ministros, que foi realizada sob os argumentos artificiosos de que tal aumento era relevante para lidar com a sobrecarga processual e para "revestir as decisões em matéria constitucional de maior prestígio, com o voto concordante de nove juízes, maioria absoluta de dezesseis" (BRASIL, 1965, p. 802).

O relatório da comissão indicou que a "necessidade, realmente imperiosa, de apressar a solução dos litígios nas instâncias superiores [...] foi a tônica de todas as críticas e o alvo de todos os projetos" (BRASIL, 1965, p. 801), e apresentou as estatísticas que embasavam esse diagnóstico:

Na alta Côrte os recursos extraordinários já passam de 58.000; os agravos, de 35.000; os mandados de segurança, de 15.000; os habeas corpus, de 42.000; um acervo de 150.000 causas! Um esfôrço despendido no julgamento delas excede as 
possibilidades humanas, ao atingirem a cifra anual (como em 1964) de 7.849 feitos terá tocado a cada Ministro relatar cêrca de oitocentas causas; e, dividindo-se êsse número pelos dias - menos de trezentos - concluiremos que a média diária para o estudo individual foi de três processos, nas escassas horas disponíveis antes e depois das sessões. Os dados movem à surpresa, ao refletirmos que, no período de um ano, a produção total da Côrte Suprema dos Estados Unidos vai pouco além de mil decisões. (BRASIL, 1965, p. 802).

A devida compreensão desse argumento da "sobrecarga" envolve uma análise da carga de trabalho do STF nos anos anteriores a 1965. Se observarmos a evolução geral do trabalho do Tribunal entre 1940 e $1964^{4}$, para ter uma visão semelhante à que tinha a Comissão em 1965, percebemos que o número anual de processos distribuídos se manteve relativamente estável ao longo da década de 1940 e, a partir do início da década de 1950, passou a crescer de forma muito mais intensa que a variação populacional do país, projetada aqui a partir dos dados dos censos decenais do IBGE. Para permitir uma comparação adequada dos dados populacionais, dividimos o total da população por 20.567, o que permite que o valor inicial da população seja idêntico à quantidade inicial dos acórdãos publicados. Embora o número de acórdãos publicados em 1940 tenha sido de 1.469, adotamos como valor inicial o de 1.985, correspondente à média do primeiro quinquênio analisado (1940-44), para evitar que variações anuais no primeiro ano da série distorcessem demasiadamente a análise. Ressaltamos que, como não há dados populacionais ano a ano sobre a população brasileira, utilizamos os censos decenais para identificar a população no início de cada década e calculamos uma população anual projetando um crescimento linear no período entre cada censo.

4 Os dados estatísticos sobre o quantitativo da demanda utilizados neste artigo foram gentilmente fornecidos pela Central do Cidadão do STF. 


\section{GRÁFICO 1 - EVOlUÇÃo dOS PROCESSOS DO STF ENTRE I940 E I964}

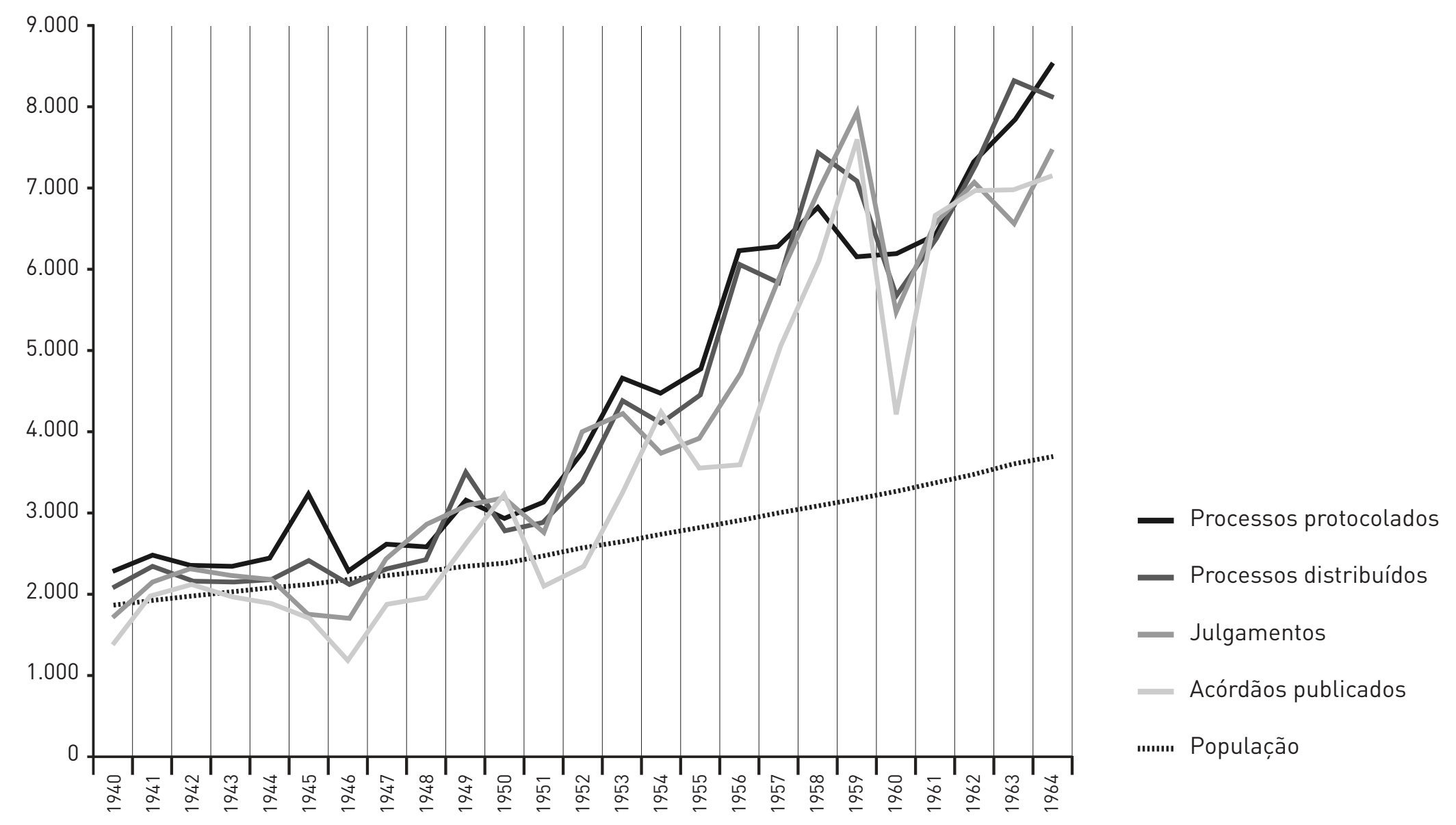

O Gráfico 1 mostra um crescimento vigoroso no número de causas entre $1940 \mathrm{e}$ 1964, que praticamente quadruplicou ao longo de duas décadas, o que parece justificar a percepção generalizada de um excesso de trabalho. Podemos notar um paralelismo entre as linhas dos processos distribuídos (azul-escuro) e dos acórdãos publicados (amarela) que indica que o aumento no ingresso de processos se reflete, no prazo de um ou dois anos, em um correspondente incremento dos acórdãos publicados. Embora a ausência de dados consolidados anteriores torne imprecisa a análise, os gráficos sugerem que houve um acentuado crescimento no número de demandas a partir da promulgação da CF de 1946. Nesse período, houve uma queda pontual da atividade judicial no ano de 1960, que provavelmente se relaciona com o trânsito do Supremo para Brasília, tendo em vista que não parece haver modificações legislativas ou situações políticas que justificassem essa alteração no padrão de atividade do STF. O gráfico sugere que, ao longo da vigência da Constituição de 1946, houve um equilibrado crescimento entre processos distribuídos e julgados, bem como um alto índice de publicação de acórdãos, sugerindo que o incremento na litigância pôde ser absorvido pelo Tribunal. A soma desses elementos justificava a percepção de uma "sobrecarga" e a busca de alternativas que evitassem um congestionamento irreparável (BRASIL, 1965, p. 803), mas ainda não conduzia ao pessimismo da percepção contemporânea consolidada na afirmação do ministro Teori 
Zavascki de que o "Supremo caminha para sua disfuncionalidade" (DIANTE POSSIBILIDADE..., 2014).

Há mais de cinquenta anos persiste o diagnóstico do descompasso entre o número de processos ajuizados no STF e a capacidade de julgá-los (BRASIL, 1965, p. 803) e ao longo desse tempo o enfrentamento de tal problema estimulou várias propostas e motivou reformas tanto constitucionais como legislativas. Estratégias propostas na década de 1960 voltaram recorrentemente à agenda de reforma do Judiciário: criação de restrições aos recursos extraordinários, instituição de um conselho da magistratura, aumento do número de juízes e tribunais, ampliação do controle concentrado, possibilidade de avocar processos para fixar rapidamente novos precedentes. Na última década, inclusive, chegou a ser implementada medida semelhante a uma das sugestões do STF que não foi acolhida pela Comissão cujo trabalho embasou o PEC 6/1965: a criação, inspirada no certiorari norte-americano, de uma nova causa de prejudicialidade dos recursos para o STF, que somente poderiam ser conhecidos quando dotados de "alta relevância na questão federal suscitada" (BRASIL, 1965, p. 802). Essa proposta, assemelhada ao atual sistema da repercussão geral, foi rejeitada sob os argumentos de que a eminência da Corte Suprema não se deve "ao exercício discricionário e às vezes discriminatório dos seus imensos poderes” e de que causaria a insegurança dos jurisdicionados diante da percepção de que o desfecho dos casos não estivesse diretamente relacionado à lei, mas dependesse de "critérios subjetivos, embora respeitáveis, mas sempre incertos e contingentes, na admissão do último apelo” (BRASIL, 1965, p. 802).

A exposição de motivos do PEC 6/1965 indica que a criação da representação de inconstitucionalidade foi uma proposta que partiu do próprio $\mathrm{STF}^{\mathbf{5}}$, bem como a sugestão de que fosse criada uma "prejudicial de inconstitucionalidade", modalidade de avocatória suscitável pelo Procurador-Geral da República ou pelo Tribunal em qualquer processo em curso, que permitiria ao Supremo chamar para si a decisão de questões de constitucionalidade submetidas a outros órgãos judiciais. Ambas as propostas reforçavam as competências do STF e restava claro que todo projeto de reforma precisava conciliar "o propósito de não diminuir, antes dilatar a competência do Supremo, em tudo que concerne à intangibilidade da lei maior, com a necessidade, sentida e denunciada em todos os pretórios, de apressar o andamento dos feitos" (BRASIL, 1965, p. 802). Nesse mesmo sentido de ampliação dos poderes do STF estava o art. 21 do PEC 6/1965, rejeitado pelo Congresso, que retirava do Senado Federal a competência para suspender a execução da lei ou ato declarado inconstitucional, dispondo que caberia à Casa legislativa apenas "fazer publicar no Diário Oficial e na Coleção de Leis, a conclusão do julgado que lhe fôr comunicado”.

5 Cabe aqui o registro de que, mesmo antes da promulgação da EC 16/1965, os ministros já debatiam a possibilidade de declaração em tese de inconstitucionalidade nas representações interventivas. Nesse sentido: STF Rp 94, 1946; Rp 95, 1947; Rp 96, 1947. 
A criação da avocatória sugerida pelo STF foi rejeitada pelo Executivo, sob o argumento de que ela "importaria em subtrair aos juízes das mais diversas categorias a faculdade, que lhes pertence, no grau de sua jurisdição, de apreciar a conformidade da lei ou ato com as cláusulas constitucionais" (BRASIL, 1965, p. 802). Já a proposta da criação da representação de inconstitucionalidade foi saudada como um instrumento de eficiência processual, pois ela teria “o mérito de facultar desde a definição da controvérsia constitucional sobre leis novas, com economia para as partes, formando precedente que orientará o julgamento dos processos congêneres" (BRASIL, 1965, p. 802). O argumento que serviu para afastar a proposta de avocatória (que poderia ser suscitada pelo próprio STF) não foi utilizado para rejeitar também a representação de inconstitucionalidade (que somente poderia ser movida pelo Poder Executivo), apesar do reconhecimento explícito de que entre nós não vigorava “o privilégio de interpretação constitucional por uma Côrte especializada” (BRASIL, 1965, p. 802), deixando revelar um interesse governamental na implantação de medidas de eficiência processual que contribuíssem para a concentração de poderes políticos no Executivo. Essa interpretação é corroborada pelo fato de que, no chamado "pacote de abril", editado no governo Geisel, a EC 7/1977 criou uma avocatória com efeitos ainda mais gerais, que possibilitaria a avocação de quaisquer causas judiciais, mas restringiu ao procuradorgeral da República a possibilidade de solicitar tal medida.

$\mathrm{O}$ estabelecimento da representação de inconstitucionalidade representou um movimento de concentração da jurisdição constitucional, com uma ampliação dos poderes do STF que só não foi completa porque o próprio Executivo rejeitou a proposta de concentrar no próprio Supremo o poder de selecionar as causas constitucionais que julgaria, por meio da avocatória, ainda que o AI-2 tenha anulado o peso político dos ministros nomeados antes de 1964 por meio da introdução de novos magistrados na Corte. Com isso, o modelo de controle concentrado instituído pela combinação do AI-2 com a EC 16/1965 foi altamente seletivo, visto que a representação somente poderia ser movida pelo representante judicial da presidência da República, cargo de confiança nomeado livremente pelo presidente e exonerável ad nutum. O sentido político dessa inovação foi reconhecido dentro do próprio STF, como indica a afirmação de Aliomar Baleeiro de que a Rp "não é uma ação, no sentido clássico, genuíno do Direito Processual. [...] É uma medida política, pouco importando que ela adote alguns dos integrantes processualistas" (STF Rp 700 AgR, 1967).

A restrição do controle concentrado à garantia dos interesses da chefia do Poder Executivo federal, ocupada pelos militares, foi consolidada em 1971 pela decisão da Reclamação 849 (STF Rcl 849), em que o Tribunal reconheceu a validade da decisão do procurador-geral de não dar seguimento a pedido do MDB no sentido da inconstitucionalidade da lei que instituiu a censura. Nesse julgamento, o único voto divergente foi do ministro Adaucto Lúcio Cardoso, que recebeu o argumento da maioria "com o maior apreço, mas com melancolia”, afirmando corajosamente que o STF "se esquiva de fazer o que a Constituição lhe atribui” e renunciou à magistratura devido à sua inconformação com o desfecho desse caso (LEAL, 1997, p. 196). 


\section{O CRESCIMENTO DAS DECISÕES MONOCRÁTICAS}

A EC 16/65 não foi qualificada na época como uma medida voltada a reduzir o número de processos na corte, mas como uma proposta voltada primordialmente para conferir celeridade aos julgamentos e, com isso, enfrentar a "crise das pautas de julgamento" (BRASIL, 1965 , p. 801). À primeira vista, os dados sugerem que essas finalidades foram relativamente alcançadas. Embora a falta de dados específicos sobre o julgamento de cada classe processual limite a possibilidade de generalizar conclusões, os dados gerais sobre os processos no STF indicam que houve uma alteração substancial de padrões de julgamento entre 1965 e 1979: o gráfico a seguir mostra que houve uma efetiva aproximação das linhas que indicam os processos distribuídos e julgados, o que sugere que nessa época o Tribunal conseguiu oferecer respostas mais céleres para uma quantidade de demandas que era crescente, mas que não era mais intensa do que o próprio crescimento populacional.

\section{GRÁfico 2 - EVOluÇÃo doS PROCESSOS Do STF ENTRE I940 E 1979}

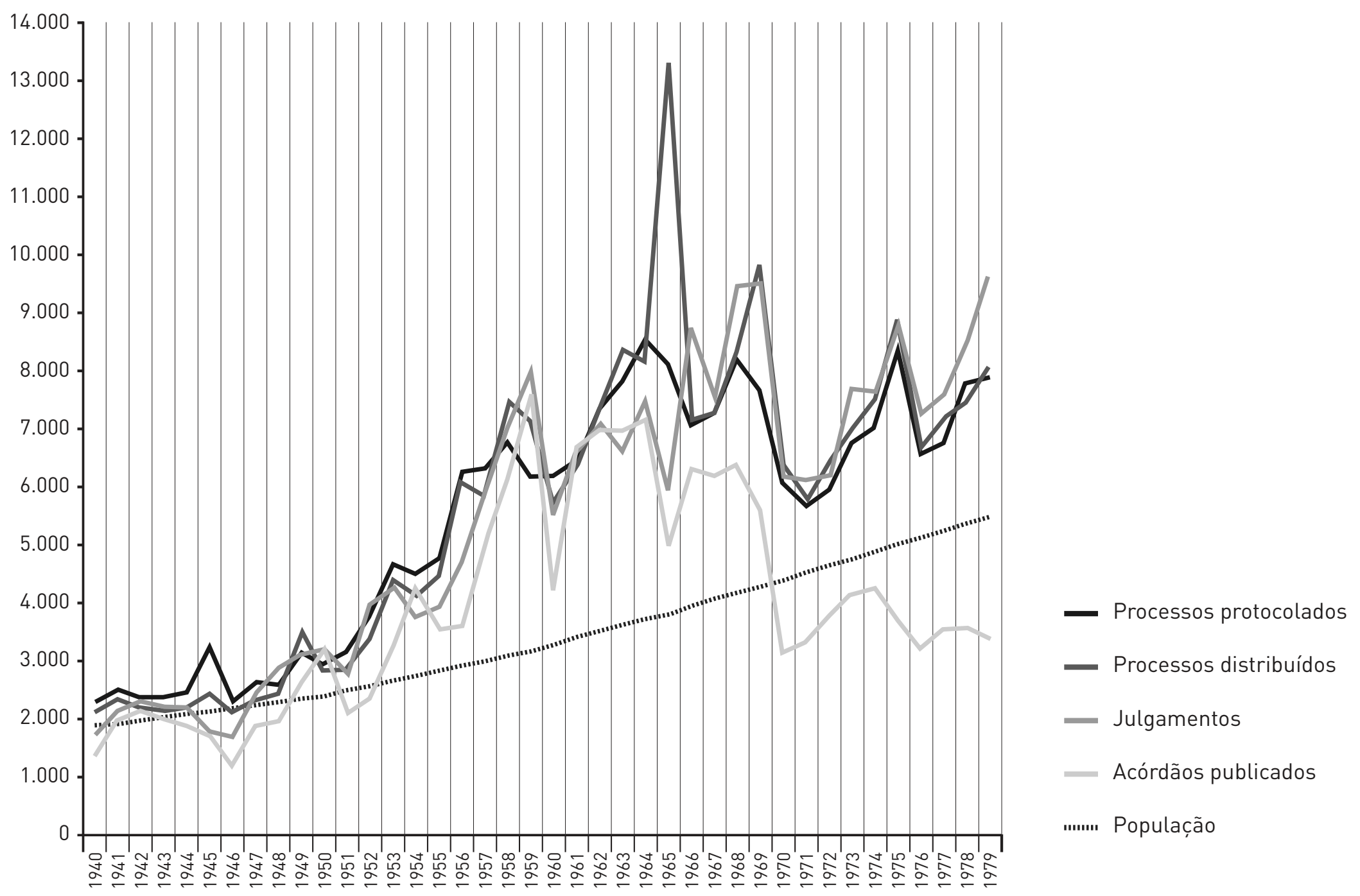


O Gráfico II indica o início de uma mudança que se consolida no final da década de 1960: um estancamento no movimento acirrado de incremento no número de processos distribuídos e julgados, acompanhado por uma redução substancial no número de acórdãos, o que sugere um sensível incremento na decisão monocrática de processos. Em 1970, esse movimento se acirrou, pois os acórdãos publicados passaram a representar pouco mais do que metade dos processos julgados, o que indica o uso sistemático de decisões monocráticas como forma de enfrentar a sobrecarga processual. Na década de 1970, o número de acórdãos publicados voltou ao patamar de meados da década de 1950, embora tenha dobrado o número de processos distribuídos e julgados e havido um crescimento substancial da população brasileira no período. Até o final dos anos 1960, as quatro linhas que indicam a evolução dos processos seguiam trajetórias semelhantes, mas a partir de 1967 torna-se evidente que a quantidade de acórdãos publicados passa a seguir um curso próprio e bastante diverso.

O novo padrão consolidou-se na década de 1970, fato compatível com a introdução de dispositivo no Regimento Interno do STF, promulgado em 1970, que criava a possiblidade de "o Relator arquivar ou negar seguimento a pedido ou recurso manifestamente intempestivo, incabível ou improcedente; e, ainda, quando contrariar a jurisprudência predominante do tribunal" (art. 22, $\S 1^{\circ}$ ). Os dados sugerem que essa ampliação dos poderes do relator teve impactos mais fortes e duradouros no padrão de atividade judicial que as mudanças introduzidas nas emendas constitucionais realizadas ao longo da década de 1970. O principal indicativo desse movimento é que, ao longo dessa década, apesar do crescimento gradual do número de julgamentos, há uma estabilização no número de acórdãos publicados, que somente vem a crescer novamente depois de 1981, quando há um vertiginoso crescimento de ajuizamentos e julgamentos no STF. Entre 1965 e 1970, observa-se uma redução da relação entre o número de acórdãos e o número de julgamentos, mas é somente a partir de 1969 que ocorre redução drástica do número de acórdãos publicados e há queda substancial no número de julgamentos, fazendo as médias quinquenais de acórdãos publicados por habitante ao longo da década de 1970 e 1980 serem menores que as médias da década de 1940 . 


\section{GRÁFICO 3 - EVOLUÇÃo DA RELAÇÃO ENTRE PROCESSOS JULGADOS E ACÓRDÃOS}

\section{PUBLICADOS}

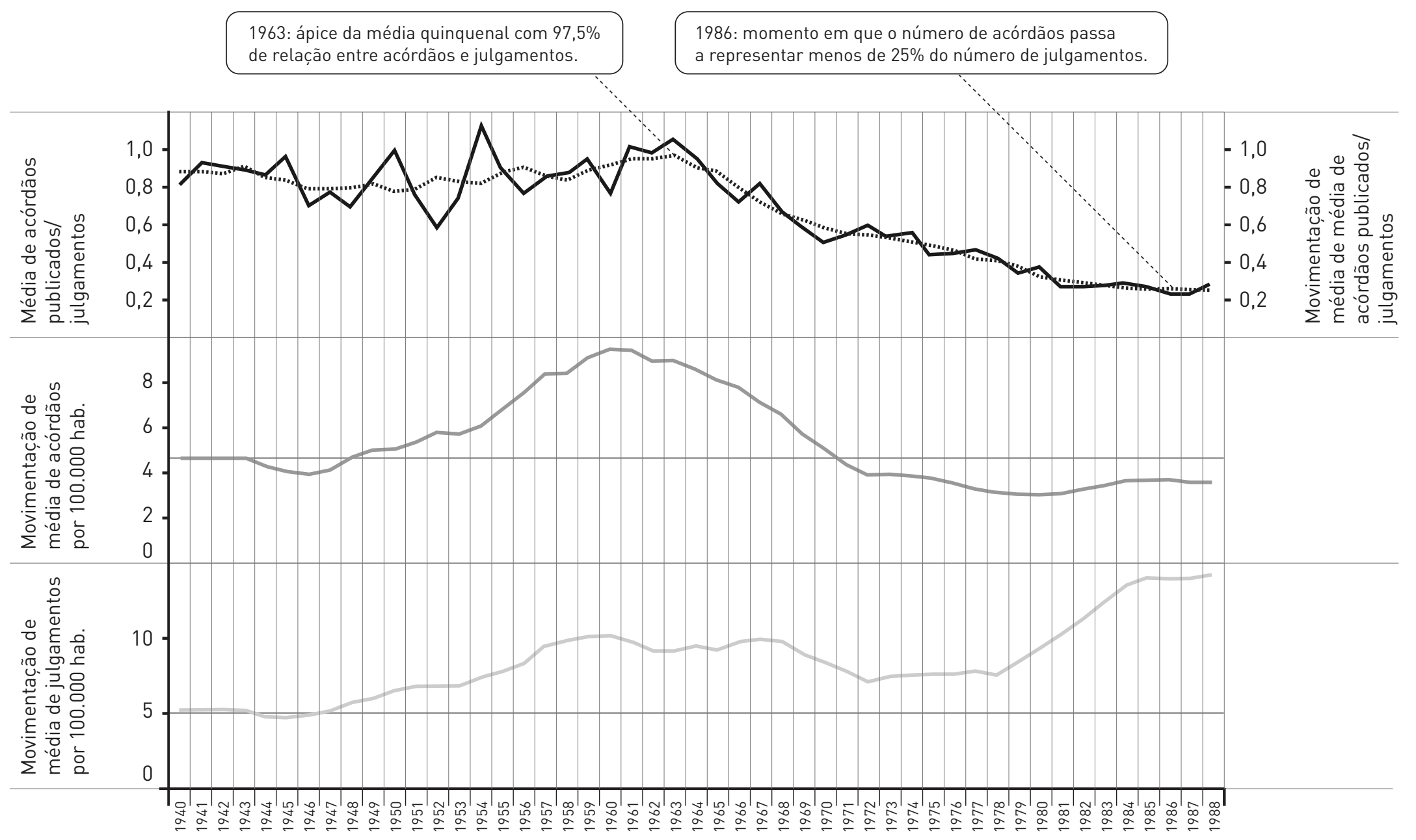

\footnotetext{
- Relação de acórdãos publicados/ julgamentos

‥'!n! Média móvel de acórdãos publicados/ julgamentos do 2 anterior para o próximo 2 ao longo da Tabela (horizontalmente)

- Média móvel de acórdãos publicados por 100.000 habitantes do 2 anterior para o próximo 2 ao longo da Tabela (horizontalmente)

- Média móvel de julgamentos por 100.000 habitantes do 2 anterior para o próximo 2 ao longo da Tabela (horizontalmente)
}

Na década de 1970, ainda que se possa falar de uma sobrecarga de trabalho, o número de processos julgados se torna consistentemente maior do que o de processos ajuizados e distribuídos. Como mostra o gráfico a seguir, esse é um padrão que continua ao longo da década de 1980, pois a quantidade de acórdãos publicados permanece estável, não obstante um crescimento gradual e intenso dos processos ajuizados. 


\section{GRÁFICO 4 - EVOLUÇÃO DOS PROCESSOS DO STF ENTRE I940-I989 (MÉDIAS QUINQUENAIS)}

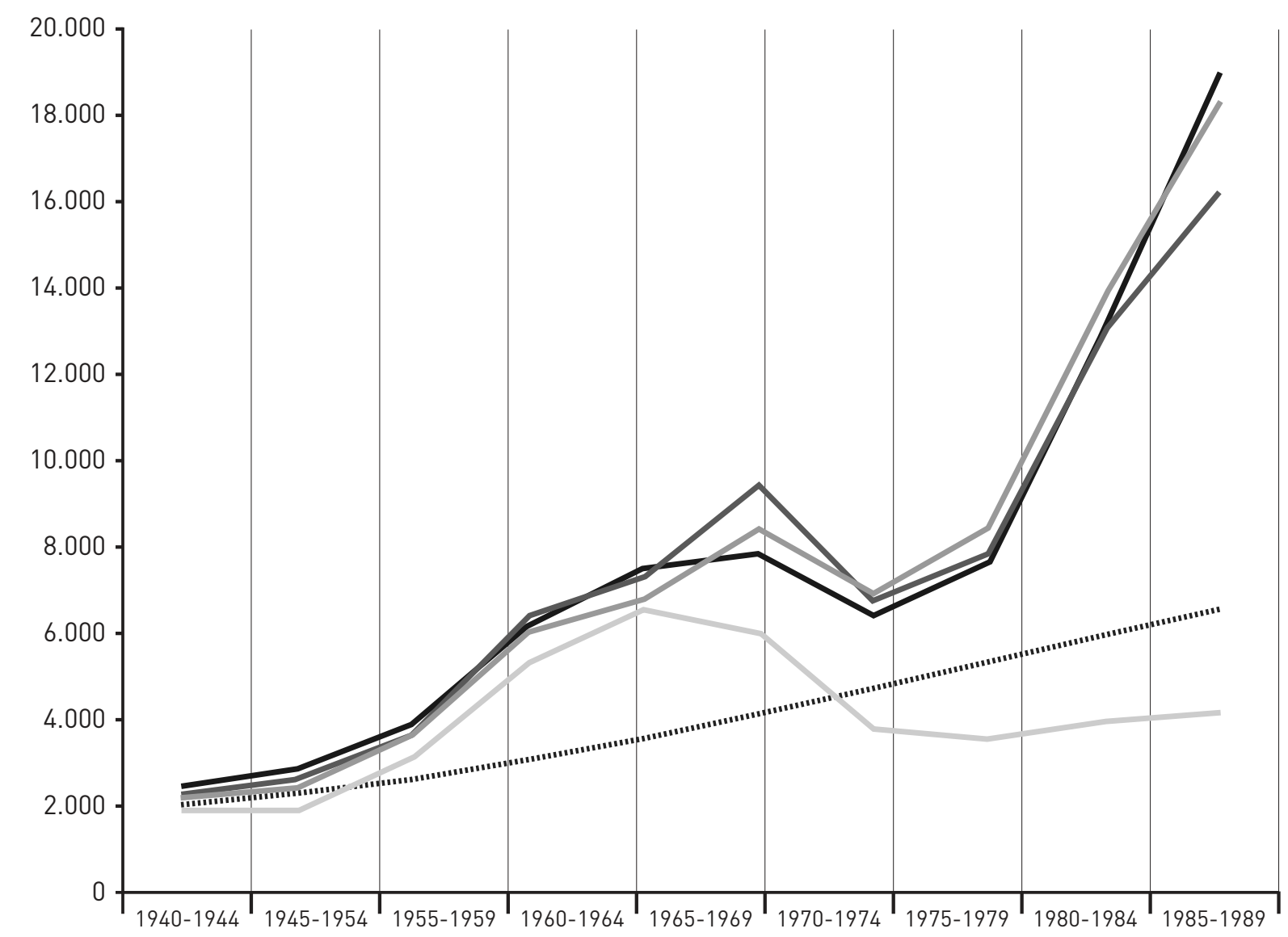

- Média de processos protocolados

- Media de processos distribuídos

- Media de julgamentos

- Média de acórdãos publicados

n'm!' Média da população

Esses dados indicam que o Tribunal adotou estratégias de trabalho que privilegiaram decisões monocráticas, nas quais os processos são extintos sem uma avaliação colegiada, e que tais políticas foram capazes de manter o equilíbrio entre o número de decisões e o de ajuizamentos e, inclusive, de reduzir os estoques de processos aguardando julgamento. Estabeleceu-se, assim, um mecanismo informal de seleção de julgamentos, em que a maior parte dos processos era extinto sem que o seu mérito fosse efetivamente analisado, fenômeno que se radicalizou ao longo da década de 1980, em que houve um crescimento vertiginoso do número de processos.

O Gráfico III sugere que a introdução da representação de inconstitucionalidade não implicou uma alteração substancial nos padrões de julgamento do STF, pois a variável que parece explicar as mudanças observadas no gráfico é o radical aumento no número de decisões monocráticas. Embora tenha ocorrido uma ligeira redução no número de processos ajuizados entre 1965 e 1970, não há indícios de que essa mudança tenha ocorrido em função da aplicação generalizada dos precedentes fixados no controle concentrado. De fato, não causa espanto o fato de ter havido uma redução no número de demandas do STF em um governo de exceção, no qual a autoridade do Supremo estava atrelada à autoridade do governo militar, que inclusive tinha alterado a composição do STF para garantir a hegemonia de suas posições. 
Tampouco causa estranheza o fato de que uma nova onda de crescimento acelerado do número bruto de processos e do número de processos por habitante somente tenha ocorrido no início da década de 1980, quando já se operavam processos políticos que indicavam o esgotamento do governo autoritário.

\section{O Debate Sobre o STF e O CONTROle Judicial de CONSTitucionalidade NA Constituinte}

A configuração institucional que deveria ter o órgão responsável pela interpretação da futura Constituição ocupou grande parte da atenção da subcomissão para o Judiciário e o Ministério Público. Composta por parlamentares eleitos para a legislatura ordinária do Congresso e não exclusivamente para a elaboração da nova Constituição, a Assembleia Nacional Constituinte (ANC) foi instalada na sessão de $1^{\circ}$ de fevereiro de 1987 e não se serviu do anteprojeto oferecido pela Comissão Afonso Arinos, que tinha recebido sugestões dos ministros do STF no sentido de manter a organização e as competências do Tribunal, conservando igualmente os mecanismos difuso e concentrado de controle de constitucionalidade, sem ampliar o número de legitimados para provocação direta da Corte (KOERNER; FREITAS, 2013, p. 147).

Embora os detalhes do funcionamento da constituinte escapem do objeto deste trabalho, a observação dos distintos momentos deliberativos da ANC merece realce, por revelar como as aspirações manifestadas pela maioria dos constituintes no ato de instalação não se converteram $^{6}$ no texto constitucional promulgado. Tratando-se de um ambiente em que a capacidade para a tomada das decisões estava fragmentada entre diversas correntes ${ }^{\mathbf{7}}$, e destacando que uma das dimensões da Constituinte é a escolha de instituições e a definição de regras, inclusive sobre o seu funcionamento, não se pode deixar de considerar que os agentes políticos envolvidos no processo tinham em conta a maximização de seus interesses na escolha

6 Como aponta o texto de Sandra Gomes, baseado em pesquisas de opinião da época, $60 \%$ dos constituintes preferiam a adoção de um texto constitucional conciso, o que não se tornou realidade; 54,4\% afirmaram ser partidários do parlamentarismo, entretanto, o presidencialismo foi mantido; o voto distrital tinha apoio de 63\% dos constituintes, porém também nesse tema o status quo prevaleceu. Cf. GOMES, 2006, p. 194.

7 A prevalência do PMDB, que tinha feito 303 parlamentares nas eleições de 1986 (54,02\% dos constituintes) contra 35 do PFL $(24,15 \%)$, fez com que aquele monopolizasse o processo decisório (CARVALHO NETO, 2007, p. 305), ocupando a relatoria de todas as comissões temáticas (um contrassenso ao princípio da proporcionalidade consagrado no Regimento da ANC). Porém, a heterogeneidade do ponto de vista ideológico e o desgaste entre constituintes pemedebistas durante o processo, além da insatisfação de parlamentares da direita com posições ditas progressistas aprovadas nas comissões dificilmente alteráveis no plenário, abriu espaço para a coalizão de veto conhecida como "Centrão", que contou com 43 constituintes do PMDB e provocou a mudança no Regimento da Constituinte. Cf. GOMES, 2006, p. 206. 
daquele quadro institucional, de modo que o procedimento adotado implica significativos custos políticos para a defesa das propostas em jogo.

Nesse cenário, o STF ocupava uma confortável e proeminente posição. Embora não explicitamente envolvido nas disputas internas do pacto constituinte, o Tribunal foi mobilizado como árbitro da organização dos trabalhos por parte da ala mais conservadora da Constituinte, especialmente na ocasião em que o Partido Liberal, opondo-se ao Regimento da Constituinte (Projeto de Resolução 1) ${ }^{8}$, encaminhou em 5 de fevereiro de 1987 consulta ao STF para que este definisse se "os procedimentos vigentes de elaboração e reforma constitucional deveriam ser observados até a promulgação da nova Constituição” (KOERNER; FREITAS, 2013, p. 149). Embora não tenha sido respondida pelo Supremo, tal consulta foi encaminhada pelo ministro Moreira Alves ao PGR para parecer, com o pedido de urgência, com o objetivo de que o Tribunal pudesse apreciá-la como arguição de inconstitucionalidade (KOERNER; FREITAS, 2013, p. 149).

Outro ponto importante é que a Subcomissão do Poder Judiciário e do Ministério Público não era uma das prioridades das disputas partidárias. Durante os trabalhos, recebeu cerca de 2 mil sugestões enviadas pela população à Constituinte, realizou onze audiências públicas com servidores da justiça, magistrados, dirigentes das associações de juízes e promotores, juristas e ministros do STF, reunindo cerca de sessenta horas de gravação desses depoimentos, para construir um amplo diagnóstico da situação do sistema de justiça do país, o que culminou com a elaboração do anteprojeto do deputado constituinte Plínio de Arruda Sampaio.

Especificamente, sobre os problemas enfrentados pelo STF, as discussões tiveram dois eixos: a sobrecarga de processos, impeditiva da realização eficiente de suas atribuições, e o papel do Tribunal como órgão responsável pela uniformização de entendimentos jurídicos relacionados à lei federal e à interpretação da Constituição. Ao debate desses problemas foi agregado o objetivo de tornar o Judiciário mais democrático e aproximá-lo da população, chegando-se a discutir a possibilidade de instituição de eleições majoritárias para os cargos de juízes e ministros. Nos anos que antecederam a Constituinte, pode-se notar que, apesar do alto volume da movimentação, o Tribunal não conservava uma acumulação de estoque para os anos seguintes, sendo notável que desde o início da década de 1970 até meados dos anos 1980, não obstante o aumento no número de processos, o número de decisões supera consistentemente o número de processos distribuídos.

Como o número de causas e de julgamentos era bastante superior ao existente antes da inclusão da representação de inconstitucionalidade em 1965, pareceria razoável esperar na ANC uma discussão acerca da eficácia daquela inovação no sentido de limitar o número de

8 A insatisfação em relação ao projeto do regimento estava nas previsões de que a ANC poderia adotar resoluções constitucionais para alterar as normas vigentes, inclusive a duração do mandato do presidente Sarney, os decretos-lei, as medidas de emergência e o decurso de prazo. 
processos, debate esse que seria importante para subsidiar a decisão acerca da instituição de uma corte constitucional, questão relevante naquele momento, mas cuja proposta foi descartada ao longo do processo constituinte. Não obstante, a análise dos trabalhos da Subcomissão do Judiciário e Ministério Público indica que o debate sobre essa temática foi bastante limitado, chegando seu relator, deputado Plínio de Arruda Sampaio, a indicar, em entrevista concedida em 2005, que ela "não foi uma comissão dividida com debates acalorados" (CARVALHO NETO, 2007, p. 310).

Um dos pontos em que um relativo consenso dos parlamentares motivou uma alteração substancial, e que representou a única derrota significativa nas teses sustentadas pelo STF, foi a ruptura do monopólio do procurador-geral da República para mover o controle concentrado, operada por uma ampliação da legitimidade para propor ADIs (FRANCO, 1986, p. 12.290). Na ANC, foram debatidas várias propostas que ampliavam a todos os cidadãos o acesso ao controle concentrado, como as de Fábio Konder Comparato, Lamartine de Oliveira e Milton dos Santos Martins, então presidente da Associação Brasileira dos Magistrados (BRASIL, 1987b, p. 45, 51, 113). Propostas dessa natureza foram debatidas na Comissão de Sistematização e não lograram sucesso, tais como as várias emendas que buscaram incluir diferentes entidades da sociedade civil como partes legítimas para propor a ação direta de inconstitucionalidade, por reconhecer que o rol de legitimados da proposta que veio a ser aprovada era demasiadamente restrito. Nesses debates, destaca-se especialmente a argumentação de Nelson Friedrich no sentido de que era preciso incluir todas as "entidades de âmbito nacional”, e não apenas as de caráter sindical, e o reconhecimento expresso de Aluízio Campos de que o sistema definido no texto constitucional permitia que a sociedade civil defendesse os direitos sociais, mas não os direitos individuais e coletivos (BRASIL, 1987b, Suplemento “C”, Comissão de Sistematização, p. 994-995).

Os movimentos de abertura do controle concentrado para a sociedade civil não prosperaram e o texto final da Constituição terminou por realizar uma tímida ampliação dos legitimados, que passaram a abranger também outros órgãos estatais (presidente da República, governadores de estado e Assembleias Legislativas), partidos políticos e entidades corporativas. Estranhamente, a ampliação da legitimidade para a propositura de ADI costuma ser festejada como uma conquista democrática, chegando o presidente da República a afirmar que esse "amplo rol de entes legitimados assegura a veiculação e a seleção qualificada das questões constitucionais de maior relevância e consistência, atuando como verdadeiros agentes de representação social e de assistência à cidadania” (BRASIL, 2000). Estranhamente, são raras as críticas que apontam no sentido de que esse rol é de fato restrito e que estabelece um modelo que exclui justamente as organizações sociais voltadas à garantia e proteção de direitos de minorias e à promoção de causas de interesse público. Tal seletividade foi posteriormente robustecida com a criação jurisprudencial do requisito de "pertinência temática”, que limitou a atuação das entidades corporativas e dos governadores de estado, de modo a impedir que eles atuassem em causas voltadas à garantia do interesse coletivo. O pré-requisito 
da repercussão geral em recursos extraordinários, criado com a EC 45/2004, insere-se nesse movimento de reforço dos poderes de seleção da corte quanto aos temas que ela considera legítimos para julgamento.

No texto da Constituição de 1988, o único ponto em que foram criadas condições para maior abertura procedimental foi a previsão genérica de que o STF deveria apreciar a arguição de descumprimento de preceito fundamental, cuja regulamentação legal poderia instituir um sistema mais amplo de acesso ao controle concentrado. De fato, ao regular essa matéria (PL 2872/1997), o Congresso Nacional enviou para a sanção presidencial um projeto de lei que reconhecia legitimidade a "qualquer pessoa lesada ou ameaçada por ato do Poder Público", mas esse dispositivo foi vetado sob o argumento de que a "admissão de um acesso individual e irrestrito é incompatível com o controle concentrado de legitimidade dos atos estatais - modalidade em que se insere o instituto regulado pelo projeto de lei sob exame" e que colocava em risco a "viabilidade funcional" do STF (BRASIL, 2000). Com isso, o texto definitivo da Lei n. 9.882/99 reforçou novamente a seletividade, instituindo essa arguição como uma forma específica de ação, e não como um incidente processual movido pelo próprio Judiciário, que é típico de sistemas de corte constitucional baseados no paradigmático modelo austríaco, e restringindo-a aos mesmos legitimados para a propositura de ADI.

\section{As Alterações nO CONTROLE DE CONSTITUCIONALIDAdE POSTERIORES À ConstituiçÃo}

A ideia de coerência lógica do ordenamento jurídico brasileiro e de necessidade de conferir segurança jurídica ao sistema de controle de constitucionalidade em função das decisões judiciais conflitantes entre os mecanismos difuso e concentrado aparece como principal elemento da construção teórica tanto da ação declaratória de constitucionalidade, quanto do efeito vinculante no Brasil, conforme consignado na PEC 130/1992 e apresentado pelo deputado Roberto Campos em suas justificativas:

Um dos problemas que mais tem preocupado o país, pelo prisma da nova ordem constitucional, é a valorização dos juizados de $1^{\mathrm{a}}$ instância - louvável conquista da cidadania - sem a contrapartida de um instrumento processual de uniformização célere, omissão incompreensível do constituinte na conformação do controle difuso e concentrado de constitucionalidade. A força outorgada aos juízes de $1^{\text {a }}$ instância, sem um instrumental adequado de ação para os Tribunais Superiores, subverte a

9 Cabe aqui o registro de que a justificativa apresentada com o projeto incorporou estudo sobre o instituto na doutrina constitucional alemã, produzido à época pelo subchefe para Assuntos Jurídicos da Presidência da República, Gilmar Ferreira Mendes. Cf. MENDES, 1999. 
hierarquia necessária - e mais do que isso - a tranquilidade para a preservação da ordem jurídica, pois qualquer questão constitucional da maior relevância pode ser decidida de forma satisfativa, desde que oTribunal imediatamente não suspenda a eficácia de decisões que garantam benefícios ou direitos. (BRASIL, 1992, p. 21.693).

A redação aprovada não contemplou a possibilidade de acesso direto ao STF pelo cidadão em função da violação de algum direito fundamental ou ainda que incidentalmente pela remessa ao Tribunal de um conflito normativo a partir de uma discussão concreta ${ }^{10}$ sobre o alcance ou aplicação de direitos fundamentais, cujo acesso ao Supremo permanecera apenas pela via recursal ou em eventual reclamação constitucional, sujeitando o texto da EC 3/1993 a críticas por ofensa aos princípios do juiz natural e acesso à Justiça. Também o chamado déficit de eficácia das decisões do STF em causas de grande repercussão jurídica e econômica, assim como para os litígios de massa em que a efetividade dos julgados dependia da atuação dos demais poderes, foi absorvido como sinais da crise de segurança jurídica, que aliada à morosidade, contribuiu para o descrédito do Judiciário como instituição.

A evolução das atividades do STF ao longo da década de 1990 mostra que houve nesse momento uma mudança muito grande no padrão dos julgamentos. De 1990 a 1994, existe certa continuidade do padrão de ajuizamento anterior: grande número de processos distribuídos, mas com uma quantidade compatível de julgamentos, em sua maioria extintos por decisões monocráticas, tendo em vista o baixo índice de publicação de acórdãos. Esse pequeno número de decisões colegiadas chama atenção especialmente nos anos de 1990 e 1991 , em que o número de acórdãos publicados volta aos patamares da década de 1940 e passa a equivaler a cerca de apenas $10 \%$ da quantidade de julgamentos produzidos pelo Tribunal.

A partir de 1995, existe um salto no número de acórdãos publicados, que termina por se estabilizar em torno de 10 mil decisões por ano, uma mudança substancial em relação aos períodos anteriores. Além disso, existe nos anos de 1997 a 2002 um grande incremento no número de causas ajuizadas, que saltam de cerca de 30 mil por ano para alcançarem pela primeira vez, em 2000, um patamar superior a 100 mil processos por ano. Apesar desse grande salto, o Tribunal conseguiu aumentar também o número de julgamentos, não havendo em nenhum momento um desacoplamento entre os processos julgados e os processos distribuídos. Além disso, fixou-se o padrão de que o número de acórdãos publicados passou a corresponder a $10 \%$ do número de processos julgados.

10 Esse é o modelo adotado em alguns dos países europeus que realizam exclusivamente o controle de constitucionalidade. Os Tribunais Constitucionais da Alemanha, Áustria e Espanha admitem a provocação direta em caso de ofensa a direito fundamental por autoridades públicas. Em outro grupo que inclui aqueles três países mais Bélgica, França, Itália e Luxemburgo os Tribunais Constitucionais recebem as chamadas questões constitucionais, a partir das discussões judiciais em casos concretos, suspendendo o litígio enquanto não é resolvida a constitucionalidade da lei. Cf. COMELLA, 2009, p. 8. 


\section{GRÁFICO 5 - EVOluÇÃo dOS PROCESSOS DO STF ENTRE I985 E 2004}

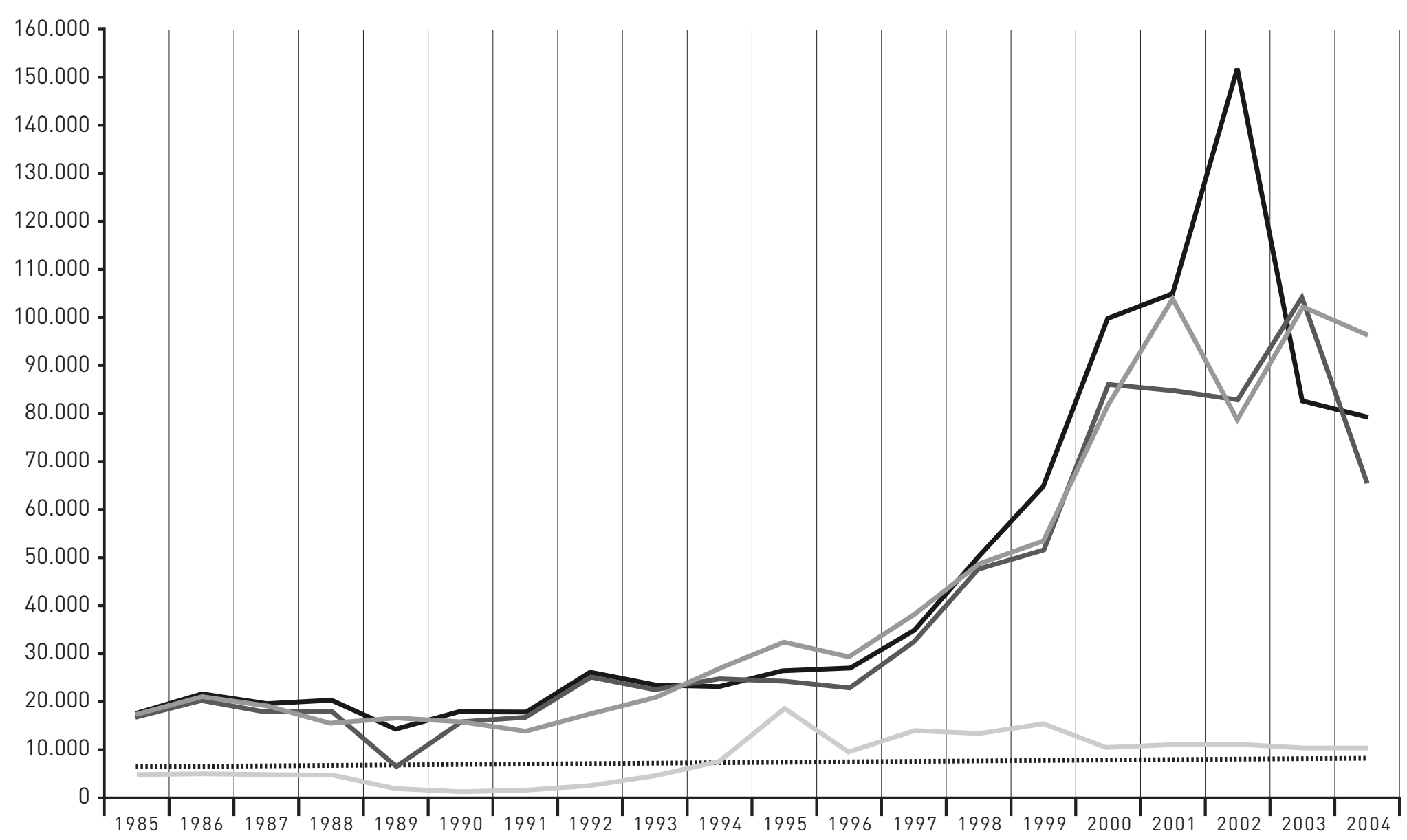

- Processos protocolados

- Processos distribuídos

- Julgamentos

- Acórdãos publicados

'."'n!' População

Essa evolução indica que as mudanças introduzidas pela EC 3/1993 não tiveram uma repercussão ampla nas decisões da Corte. O argumento da segurança jurídica constituiu o principal fundamento da ideia de vinculação das decisões do STF incluída na Emenda, que trazia como referência os exemplos dos Tribunais Constitucionais europeus como modelo para assegurar a aplicabilidade dos direitos fundamentais a partir de um parâmetro de controle de constitucionalidade pautado pela racionalidade, e que se revelava incompatível com a excessiva carga de trabalho submetida à Suprema Corte brasileira. Outro passo, com a mesma justificativa, foi a aprovação da Lei n. 9.868/1999, que disciplinou o processo e julgamento das ações diretas, ampliando o alcance das deliberações da Corte com a extensão do efeito vinculante à chamada "interpretação conforme", tanto em relação aos demais órgãos do Judiciário quanto à Administração Pública. Entre os fundamentos para a utilização da 
interpretação conforme a Constituição, ainda sem previsão constitucional ou legal, estava a exigência prática de suprir um eventual vazio no ordenamento jurídico, resultante da declaração de inconstitucionalidade. Logo, a necessidade de conferir ao Supremo a faculdade de proferir sentenças interpretativas articulava-se com a conservação de atos jurídicos produzidos com base na lei questionada em homenagem à segurança jurídica à semelhança das sentenças interpretativas da Corte Constitucional da Itália.

Mesmo após a sua incorporação pela Lei n. 9.868/99, as nuances que cercam a interpretação conforme a Constituição não passaram despercebidas, dada a possibilidade de o Tribunal pretender "melhorar" o texto da norma impugnada, desvinculando-se da literalidade da redação aprovada pelo Poder Legislativo para sobrepor a interpretação dos magistrados à dos legisladores. Não obstante a fluidez dos "limites" da interpretação conforme a Constituição, construídos doutrinariamente e pela jurisprudência, a constitucionalidade da sua previsão na Lei n. 9.868/99 foi reconhecida pelo Plenário da Corte (STF, Rcl 1880, AgR-QO, 2002). Com isso, consolidou-se o uso da reclamação constitucional como forma de "amparo" aos eventuais prejudicados pela inobservância ao efeito vinculante, com acirramento da tendência concentradora da jurisdição constitucional na Suprema Corte, acompanhada de fragilização do controle difuso.

Assim como em outras ocasiões relatadas, observa-se que a decisão da Corte avançou no estabelecimento dos limites de suas próprias competências constitucionais numa discussão lida pela comunidade jurídica como técnica, mas que possui uma dimensão política da maior relevância, já que, caso observada atentamente, põe em xeque duas premissas do constitucionalismo, fundamentais à própria sustentação do controle de constitucionalidade: 1) a separação de poderes, quando em risco a distinção da função da Corte em relação à do legislador, colocando-os sob parâmetros de concorrência na definição da escolha do próprio texto legal (HABERMAS, 2012, p. 324); 2) a imparcialidade judicial, conduzida ao paradoxo de que, mesmo vinculada ao dogma de não legislar em causa própria, a Corte passa a deliberar sobre as condições institucionais do exercício da própria função (VERMEULE, 2012, p. 396).

Apesar da profundidade das mudanças introduzidas pela Lei n. 9.868/99 e do seu grande impacto no padrão de julgamento específico das ADIs, especialmente na redução drástica do número de liminares concedidas e dos julgamentos monocráticos (COSTA; BENVINDO, 2014), essa lei não trouxe maiores repercussões nos padrões gerais de julgamento do Tribunal. Continuou a tendência de crescimento no ajuizamento, equilibrada por um incremento nas decisões monocráticas.

A última das alterações constitucionais com forte impacto para o controle de constitucionalidade no país foi a EC 45/2004. Assim como em outras ocasiões, a preocupação quanto ao exponencial crescimento de demandas submetidas ao STF somou-se ao discurso sobre as funções da Corte como instituição encarregada da guarda dos direitos fundamentais, que precisava se adequar às mudanças do próprio Estado brasileiro, em busca de celeridade e eficiência 
quanto à realização de despesas para sua manutenção, preocupações, em grande parte, motivadoras da proposta de reforma do Judiciário.

De fato, havia ocorrido um salto significativo no número de processos distribuídos e julgados, que mais do que quadruplicaram durante o processamento do projeto de reforma do Judiciário (PEC 96/1992) apresentado por Hélio Bicudo. Essa PEC recebeu inúmeras emendas tanto na Câmara quanto no Senado, onde passou a ser relatada por Bernardo Cabral, sucedido por José Jorge. A demora na tramitação e o grande número de alterações do projeto não significam, contudo, que o tema tenha causado impasses ou polarizações mais fortes no Congresso (CARVALHO NETO, 2007, p. 322). Só após treze anos, foi aprovada a EC 45, publicada em 31 de dezembro de 2004, redesenhando algumas funções da cúpula do Judiciário, dentre elas: a transferência para o STJ da competência para a homologação da sentença estrangeira e a concessão de exequatur às cartas rogatórias, além do deslocamento da competência para o julgamento de recurso extraordinário de decisão que julgar válida lei local contestada em face de lei federal do STJ para o STF, uma medida que se contrapôs ao discurso da sobrecarga do Supremo, que era um dos móveis da reforma. Também foi instituída a repercussão geral das questões constitucionais discutidas no caso para o conhecimento do recurso extraordinário e a súmula vinculante. Essas inovações consolidaram o processo de concentração do controle de constitucionalidade no Brasil na Suprema Corte (CARVALHO, 2012, p. 198). Condicionou-se, ademais, a decretação da intervenção federal a provimento do STF e foi criado o Conselho Nacional de Justiça.

Inicialmente, a EC 45/2004 não trouxe mudança substancial para o julgamento dos processos no STF, mas a partir de 2007 nota-se mudança muito grande na atuação da Corte, descrita no gráfico a seguir. 


\section{GRÁfico 6 - EVOLUÇÃo DOS PROCESSOS DO STF ENTRE 2000 E 2013}

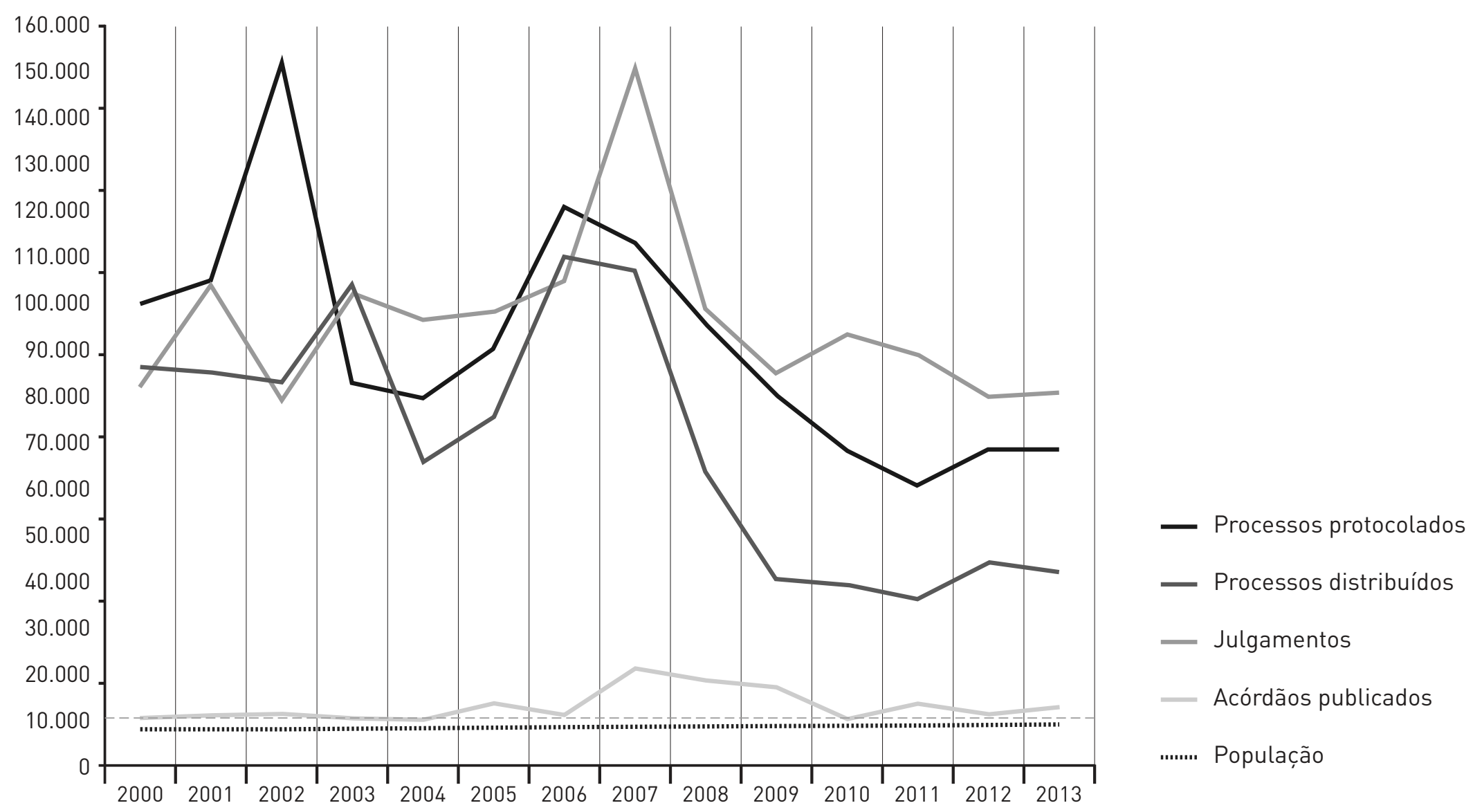

Esses dados mostram que houve, especialmente desde 2008, aumento do percentual de processos ajuizados que não são distribuídos e também número de julgamentos bastante superior às distribuições (e mesmo em relação ao protocolo), o que indica forte diminuição nos estoques de processos aguardando julgamento. A partir desse momento, houve estabilização nos números de processos ajuizados e distribuídos, bem como no número de julgamentos. E o número de acórdãos publicados, que alcançou o pico de mais de $20 \mathrm{mil} \mathrm{em}$ 2007, reduziu-se nos anos posteriores até alcançar o patamar de cerca de $10 \mathrm{mil}$ a $15 \mathrm{mil}$ acórdãos, que tinha sido mantido desde meados da década de 1990.

A combinação desses dados indica que a evolução da carga de trabalho do STF não parece ter sido tão grave quanto indicam alguns discursos. Em especial, se compararmos a evolução dos números globais de ajuizamento/julgamento do STF com a evolução populacional do Brasil, os dados mostram-se menos dramáticos. 


\section{GRÁfico 7 - EVOLUÇÃO DOS PROCESSOS, POR QUINQUÊNIOS}

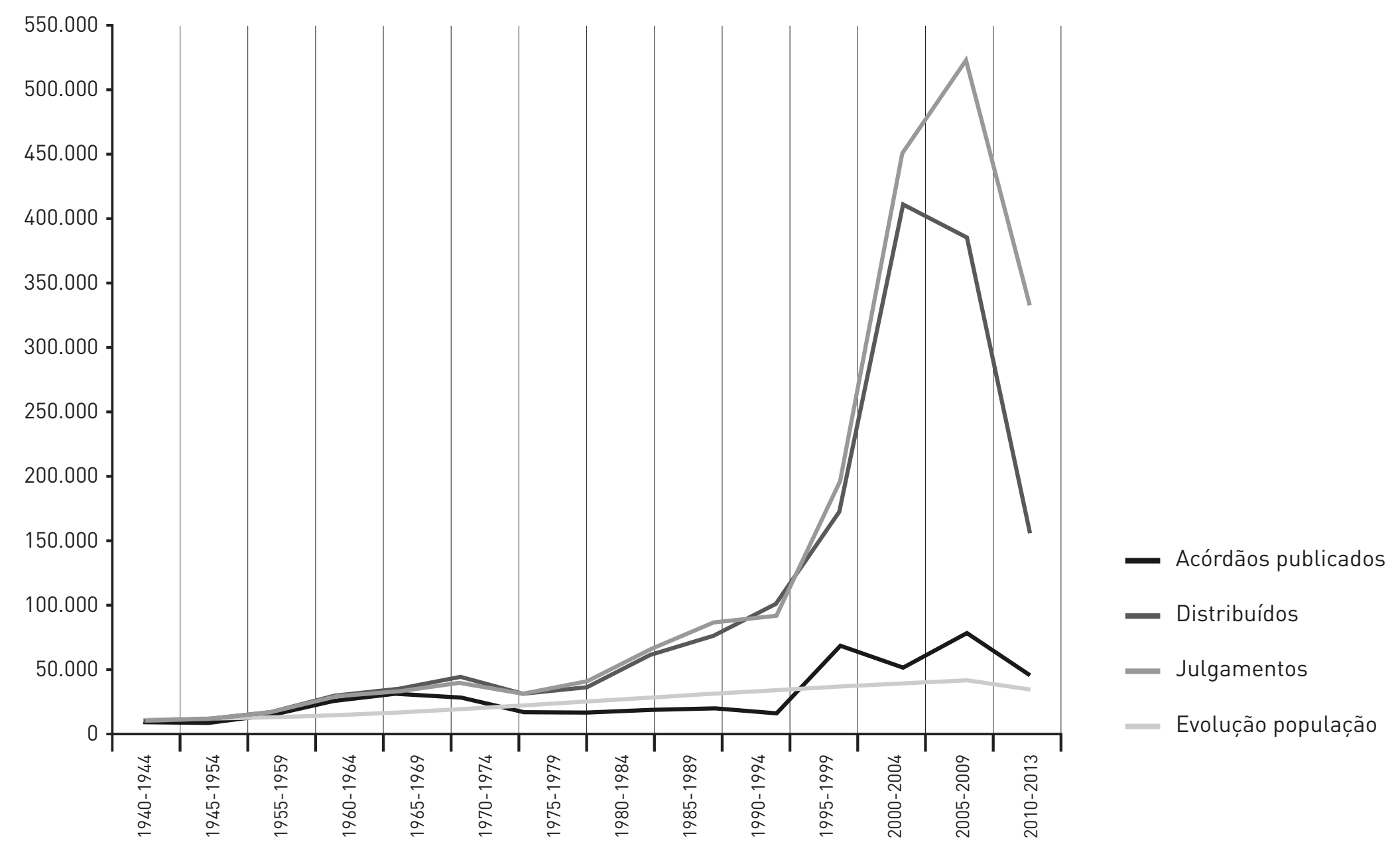

$\mathrm{Na}$ década de 1950, houve avanço relativamente equilibrado de todos os indicadores, em intensidade maior do que o aumento populacional. Já na década de 1960, houve manutenção do equilíbrio entre esses números, alterado na década de 1970, em face do incremento das decisões monocráticas, o que reduziu o número da publicação de acórdãos para $50 \%$ do número do total de julgamentos. Esse quadro se acirrou na década de 1980, com queda proporcional no número de acórdãos, mas a evolução da população foi maior que a dos processos do STF. Já nas décadas de 1990 a 2000, há avanço do número de processos ajuizados e julgados em ritmo muito maior do que o populacional, mas fica mantida a imensa preponderância dos processos julgados monocraticamente. Assim, por mais astronômicos que sejam os números dos julgamentos de processos pelo STF, percebe-se a existência da relação entre acórdãos publicados e o crescimento populacional, indicando que, durante várias décadas, a população cresceu mais do que as decisões colegiadas. Além disso, o nível alcançado na década passada indica uma relação acórdão/habitante semelhante à que existia nas décadas de 1950 e 1960, próximo a 9 acórdãos/100.000 hab. 


\section{GRÁfICO 8 - DECISÕES E PROCESSOS POR I 00.000 HABITANTES}

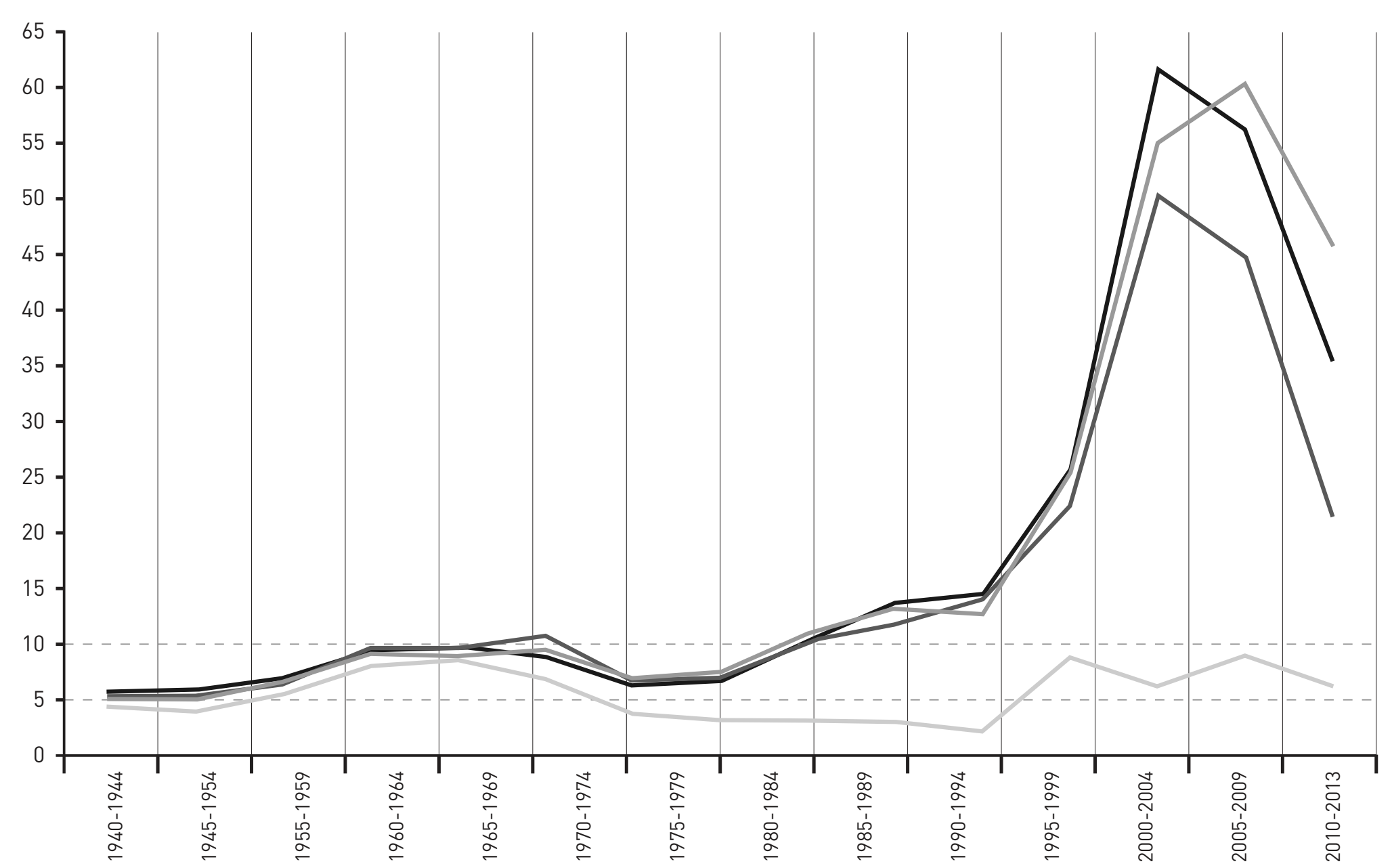

Média de processos protocolados por 100.000 habitantes

Média de processos distribuídos por 100.000 habitantes

Média de julgamentos por 100.000 habitantes

Média de acórdãos por 100.000 habitantes

Dessa maneira, fica claro que a grande sobrecarga de trabalho se concentra hoje no processamento e julgamento monocrático de milhares de processos que são apreciados em termos de sua extinção por critérios formais ou por aplicação da jurisprudência dominante. Nesse contexto, as medidas que mostraram maior impacto no funcionamento do Tribunal não foram as Emendas Constitucionais que alteraram os elementos do controle concentrado (que é minoritário), mas as modificações legais e regimentais que aumentaram o poder dos relatores para extinguir os processos.

Também tiveram impacto significativo as emendas que impediram o envio ao Tribunal de processos sobrestados pela pendência de julgamento de ação com efeito geral. Esse impacto, contudo, deve ser analisado com cuidado, tendo em vista que a diminuição de protocolos no 
STF não significa que esses processos tenham sido extintos, mas apenas que eles foram represados em outros órgãos judiciais.

De todo modo, os resultados indicam que as estratégias que mais influenciaram o perfil dos julgamentos foram as de seletividade ligadas ao controle difuso, por meio das quais houve a concentração de poder nos relatores e nas decisões que negam repercussão geral. Já as estratégias de vinculação, concentração e de abstrativização, ligadas a um fortalecimento do controle concentrado, não parecem ter impactado esses números com igual vigor.

\section{CONSIDERAÇÕES FINAIS}

A partir de 1965 tem se assistido quase que passivamente ao aprofundamento da concentração de competências em torno do STF. A Constituição de 1988 ampliou, timidamente, o rol de agentes legitimados a postular a inconstitucionalidade de lei ou ato normativo federal ou estadual perante a Corte - atribuição que, até então, era confiada exclusivamente ao procurador-geral da República. Além disso, foram instituídos instrumentos outros, sejam eles voltados ao exercício do controle de constitucionalidade por via direta, como a ação declaratória de constitucionalidade e arguição de descumprimento de preceito fundamental; sejam para a efetivação de direitos fundamentais contra omissões dos poderes instituídos na regulamentação do seu exercício, como o mandado de injunção e a ação direta de inconstitucionalidade por omissão; ou para a preservação da competência e autoridade das decisões da Corte, por via incidental, como a reclamação constitucional.

Tanto as modificações realizadas ainda no regime militar, como a representação de inconstitucionalidade, quanto as alterações posteriores à Constituição de 1988, como a EC 3/1993, que inseriu a ADC e o efeito vinculante, a Lei n. 9.868/1999, que normatizou a interpretação conforme, e, por último, a EC 45/2004, que trouxe a repercussão geral e as súmulas vinculantes, estiveram apoiadas no mesmo discurso: o ganho de eficiência no sistema de controle, prestando-se em última instância à centralização da interpretação constitucional no âmbito do STF, o que não deixou de produzir consigo uma significativa perda para a democratização do acesso à justiça, no seu sentido qualitativo e não quantitativo.

Porém, é preciso avaliar criticamente o significado desse percurso em direção ao modelo concentrado e os argumentos que lhe proveram fundamentação. A partir da análise dos dados e dos discursos que motivaram a construção do complexo sistema de controle jurisdicional hoje existente, torna-se razoável considerar que foi edificado um "castelo de areia” da segurança jurídica e economia processual. Nesse cenário, as discussões sobre as iniciativas ${ }^{11}$ de reforma

11 Nesse ponto cabe anotar a proposta da EC 342/2009, de Flávio Dino (PC do B), que extingue a vitaliciedade e estabelece mandatos de onze anos para os ministros, que passariam a ser escolhidos pelo próprio STF e pelas Casas do Congresso após a formação de listas tríplices elaboradas pelos Tribunais Superiores, Conselho Nacional de Justiça, Conselho Nacional do Ministério Público, Conselho Federal da Ordem dos Advogados e 
do perfil da Corte, assim como da própria função da jurisdição constitucional no país, não podem deixar em segundo plano uma avaliação institucional do comportamento do STF nas últimas décadas, que tem sido caracterizado pela pretensão de uma ampla vinculação normativa de fatos valorados sob o seu estrito racionalismo autorreferente, cujo resultado tem representado muito pouco para o aumento da eficiência na jurisdição constitucional.

Após tantas reformas constitucionais e legislativas, o que se tem visto é o esgotamento do discurso de que aperfeiçoar mecanismos processuais à disposição do STF e ampliar ao máximo os efeitos de suas decisões são os meios mais adequados para o aumento da eficiência jurisdicional, garantindo a segurança jurídica. Esse argumento, utilizado especialmente na justificação dos processos de concentração, vinculação e abstrativização, aponta que é preciso ter uma corte mais eficiente para que ela possa realizar o seu papel verdadeiramente constitucional, que é ligado muitas vezes ao controle concentrado e abstrato de normas (FALCÃO; CERDEIRA; ARGUELHES, 2012). Porém, o contínuo aumento das causas pela via difusa atesta que as medidas de concentração, vinculação e abstrativização não melhoraram a tutela jurídica, pois os jurisdicionados continuam precisando recorrer à Corte para ter seus direitos constitucionais reconhecidos. Por outro lado, conforme pesquisa de Alexandre Costa e Juliano Benvindo, a maior parte das decisões proferidas pela via do controle concentrado após 1988 não se prestou à tutela de direitos subjetivos, mas apenas à resolução de conflitos institucionais e federativos ou à proteção de prerrogativas corporativas (COSTA; BENVINDO, 2014).

O discurso de aperfeiçoamento da eficiência, apesar de bem-intencionado, não parece refletir efetivamente a prática judicial da corte. As modificações que alteraram mais profundamente o funcionamento do tribunal não foram as que reforçaram o controle abstrato, mas aquelas que alteraram o processo de julgamento por meio da ampliação dos poderes dos relatores de decidir monocraticamente, que atingem todos os processos de forma idêntica. Além disso, a pesquisa evidencia o grande impacto de estratégias de seletividade, que são especialmente vinculadas ao controle concreto e difuso, na medida em que não se cogitou ainda a introdução de filtros específicos no âmbito do controle concentrado no sentido de torná-lo mais efetivo na defesa dos direitos fundamentais do que na proteção de interesses corporativos. De todo modo, os dados evidenciam que as estratégias de concentração não modificaram sensivelmente a atuação do tribunal nem tiveram repercussão relevante no que toca à questão da sobrecarga de trabalho, que sempre foi o argumento utilizado para justificar a concentração.

pelas Faculdades de Direito. Além da mais recente PEC 275/2013, de Luiza Erundina (PSB), que cria uma Corte Constitucional no lugar do STF, aumentando a composição para quinze membros com idade entre 40 e 60 anos, nomeados pelo Presidente do Congresso após aprovação pela maioria absoluta das duas Casas. A nova Corte teria competência exclusiva para questões constitucionais, deslocando todas as demais para o STJ. 
O insucesso das medidas de centralização do controle de constitucionalidade é relevante para uma análise mais cuidadosa das propostas que alinham de forma necessária os procedimentos de concentração e de abstrativização, cuja união não pode ser naturalizada, apesar do reconhecimento de que ela é típica de nossa história constitucional. Outra união que deve ser desnaturalizada, apesar de perpassar a retórica da corte, é a que alinha controle abstrato e processo objetivo. Como ressalta Leonardo Martins, existe apenas um "suposto movimento de objetivação do processo constitucional brasileiro” (MARTINS, 2010, p. 128), visto que “o processo objetivo, i.e., não litigioso, que não implica partes processuais" (MARTINS, 2010, p. 138) é incompatível com várias das características do controle abstrato brasileiro, como a limitação dos legitimados e o requisito de pertinência temática. $\mathrm{O}$ controle concentrado pode se dar a partir de situações concretas e o controle abstrato pode ser movido por processos de índole subjetiva, ligados preponderantemente à defesa judicial dos interesses dos atores legitimados. Não obstante, todas as soluções que perpassam o discurso judiciário e as estratégias legislativas têm imposto um aumento na concentração de poderes nas mãos do STF, para que ele decida que casos julgar, que vozes ouvir e que efeitos atribuir a suas próprias decisões.

As várias reformas levadas a cabo nos últimos cinquenta anos, embora tenham sido recorrentemente justificadas por um discurso de melhoria da eficiência, não lograram reduzir a sobrecarga da Corte. Houve mudanças na jurisdição constitucional de duvidoso caráter democrático, em que várias vezes o argumento da "sobrecarga processual” parece não ter passado de pretexto para a efetivação de medidas de concentração de poderes na Suprema Corte, como foi o caso do AI-2 e da EC 16/1965. Não obstante, o fundamento para mudanças, ainda no presente, é aquele da década de 1960: deve-se aumentar a concentração e a seletividade do controle de constitucionalidade (o que significa ampliar os poderes do STF em detrimento das instâncias políticas), para enfrentar a sobrecarga de processos. Essa justificativa tem ressonância no senso comum teórico dos juristas e isso ofusca a circunstância de que o paulatino aumento da concentração não se mostrou adequado para resolver o problema da racionalidade da jurisdição. Aceitam-se, assim, medidas centralizadoras sob a capa de uma justificação técnica, sem reflexões mais detidas, que desvelem seu sentido político.

Uma avaliação consistente do modelo de jurisdição constitucional brasileira deve levar em conta o custo democrático de ter uma instituição de caráter contramajoritário, incumbida da proteção dos direitos das minorias, como condição da própria manutenção das regras do jogo (COMELLA, 2007, p. 172, 182), cuja concentração demasiada de poderes (especialmente por meio de decisões em abstrato e de decisões monocráticas) afeta não só o seu próprio desempenho, mas também tem o potencial de restringir iniciativas democráticas da construção do sentido desses direitos ou dificultar a sua realização por outras vias, que não a judicial.

Para finalizar, um registro importante: a oportunidade que se abre a partir da análise dos dados empíricos levantados na pesquisa "A quem interessa o controle concentrado de constitucionalidade?" e do comportamento da Corte pode ser o início da construção de um 
modelo que, afora seja capaz de reduzir a complexidade e fornecer respostas, não crie mais mecanismos de cristalização jurisprudencial em descompasso com a realidade. Afinal, tudo que a jurisdição brasileira não precisa mais é da sobreposição de uma razão pautada pela convergência entre o pragmatismo na redução da carga de trabalho e o interesse restrito às questões formais ou corporativas, o que tornaria ainda mais escassas as possibilidades de realização dos direitos fundamentais em situações concretas.

\section{REFERÊNCIAS BIBLIOGRÁFICAS}

ALENCAR, Ana Valderez Ayres Neves. A competência do Senado Federal para suspender a execução dos atos declarados inconstitucionais. Revista de Informação Legislativa, Brasília, ano 15, n. 57, jan.-mar. 1978.

BARACHO JÚNIOR, José Alfredo de Oliveira. A jurisdição constitucional nos Estados Unidos, na Alemanha e no Brasil. In: SAMPAIO, José Adércio Leite (Coord.). Constituição e crise política. Belo Horizonte: Del Rey, 2006.

BARBOSA, Leonardo. História constitucional brasileira: mudança constitucional, autoritarismo e democracia no Brasil pós-1964. Brasília: Edições Câmara, 2012.

BARROSO, Luís Roberto. O controle de constitucionalidade no direito brasileiro. São Paulo: Saraiva, 2009.

BRASIL. Assembleia Nacional Constituinte. Atas de Comissões. Subcomissão do Poder Judiciário e do Ministério Público. Ata da $2^{a}$ Reunião Extraordinária, realizada no dia 14.04.1987 - notas taquigráficas. Brasília, Câmara dos Deputados, 297p, 1987a.

Assembleia Nacional Constituinte. Resolução 2, de 25 de março de 1987. Diário da Assembleia Nacional Constituinte, Brasília, p. 871, 25 mar. 1987b. Disponível em: <http://www2.camara.leg.br/ legin/fed/resaco/1980-1987/resolucaodaassembleianacionalconstituinte-2-25-marco-1987-592261publicacaooriginal-117307-pl.html>. Acesso em: 4 fev. 2016.

Regimento Interno do STF. Diário da Justiça, Poder Executivo, Brasília, p. 1, 4 set. 1970.

Disponível em: <http://www.stf.jus.br/arquivo/cms/bibliotecaConsultaProdutoBibliotecaRI/anexo/ RegimentoInterno1970Original.pdf $>$. Acesso em: 4 fev. 2016.

. Presidência da República. Mensagem 19/1965. Encaminha o PEC 6/1965 ao Congresso Nacional. 
Diário do Congresso Nacional, p. 800, 6 nov. 1965. Disponível em: <http://imagem.camara.gov.br/ diarios.asp?selCodColecaoCsv=J>. Acesso em: 4 fev. 2016.

BRASIL. Presidência da República. Mensagem 1.807/1999. Diário do Congresso Nacional, p. 4.593, 30 mar. 2000. Disponível em: <http: / /imagem.camara.gov.br/diarios.asp?selCodColecaoCsv=J>. Acesso em: 4 fev. 2015.

Proposta de Emenda à Constituição n ${ }^{\circ}$ 130. Diário do Congresso Nacional, p. 21.693, 23 set. 1992. Disponível em: <http://imagem.camara.gov.br/diarios.asp?selCodColecaoCsv=J>. Acesso em: 4 fev. 2015.

BRUST, Leo. A interpretação conforme a constituição e as sentenças manipulativas. Revista Direito GV, v.

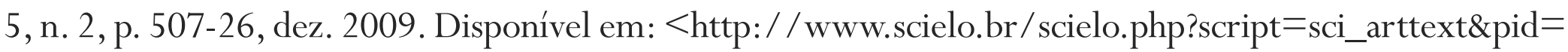
S1808-24322009000200014\&lng=en\&nrm=iso\&tlng=pt>. Acesso em: 4 fev. 2016.

CABRAL, Bernardo. A palavra do relator. Ontem, há vinte anos. Revista de Informação Legislativa, Brasília, ano 45, n. 179, jul.-set. 2008.

CARVALHO, Alexandre. Efeito vinculante e concentração da jurisdição constitucional no Brasil. Brasília: Consulex, 2012.

CARVALHO NETO, Ernani Rodrigues. A ampliação dos legitimados na Constituinte de 1988: revisão judicial e judicialização da política. Revista Brasileira de Estudos Políticos, Belo Horizonte, n. 96, p. 293 325, jul.-dez. 2007.

COMELLA, Víctor Ferreres. Constitutional Courts and Democratic Values: a european perspective. New Heaven: Yale University Press, 2009.

Justicia Constitucional y Democracia. Madrid: Centro de Estudios Políticos y Constitucionales, 2007.

COSTA, Alexandre Araújo. O poder constituinte e o paradoxo da soberania limitada. Teoria \& Sociedade, Belo Horizonte, UFMG, v. 19, p. 198-227, 2011.

; BENVINDO, Juliano. A quem interessa o controle concentrado de constitucionalidade? $\mathrm{O}$ descompasso entre teoria e prática na defesa dos direitos fundamentais. Pesquisa financiada pelo CNPq. Brasília: Universidade de Brasília, 2014. Disponível em: http://papers.ssrn.com/sol3/papers.cfm? abstract_id=2509541. Acesso em: 11 nov. 2014. 
DIANTE POSSIBILIDADE de inviabilização, Barroso pede revolução para STF. Consultor Jurídico, 21 jun. 2014. Disponível em: <http://www.conjur.com.br/2014-jun-21/diante-possibilidade-inviabilizacaoministro-revolucao-stf $>$. Acesso em: 4 fev. 2016.

FALCÃO, Joaquim; CERDEIRA, Pablo de Camargo; ARGUELHES, Diego Werneck. I Relatório Supremo em Números. Rio de Janeiro: FGV Direito Rio, 2012. Disponível em: <http://hdl.handle.net/ 10438/10312>. Acesso em: 4 fev. 2016.

FRANCO, Afonso Arinos de Melo. Exposição de motivos. Diário da Justiça, 14 jul. 1986, p. 12289 12295. Disponível em: <http://www.stf.jus.br/arquivo/biblioteca/PastaSTF/Curiosidades/1986_jul_ 14.pdf>. Acesso em: 4 fev. 2016.

GOMES, Sandra. O impacto das regras de organização do processo legislativo no comportamento dos parlamentares: um estudo de caso da Assembleia Nacional Constituinte (1987-1988). Dados - Revista de Ciências Sociais, Rio de Janeiro, v. 49, n. 1, p. 193-224, 2006.

HABERMAS, Jürgen. Direito e democracia: entre facticidade e validade. Trad. Flávio Beno Siebeneichler. Rio de Janeiro: Tempo Brasileiro, 2012. v. 1.

KOERNER, Andrei; FREITAS, Lígia. O Supremo na Constituinte e a Constituinte no Supremo. Lua Nova, São Paulo, n. 88, p. 141-184, 2013.

LEAL, Victor Nunes. Problemas de direito público e outros problemas. Brasília: Ministério da Justiça, 1997. v. 2. (Série Arquivos do Ministério da Justiça).

MARTINS, Leonardo. A retórica do processo constitucional objetivo no Brasil. In: NOVELINO, Marcelo (Org.). Leituras complementares de constitucional: Controle de Constitucionalidade. Salvador: JusPodium, 2010.

MENDES, Gilmar Ferreira. O efeito vinculante das decisões do Supremo Tribunal Federal no processo de controle abstrato de normas. Presidência da República. Subchefia para Assuntos Jurídicos. Revista Jurídica Virtual, 10, Brasília, v. 1, n. 4, ago. 1999.

VERMEULE, Adrian. Contra Nemo Iudex in Sua Causa: the limits of impartiality. Yale Law Journal, n. 122 p. 384-420, 2012. 
CONTROLE DE CONSTITUCIONALIDADE NO BRASIL: : $\mathbf{1 8 7}$

\section{Alexandre Araújo Costa}

Doutor em Direito pela Universidade de Brasília (UnB).

Professor adjunto da UnB. CoORdenador do Grupo de

Pesquisa em Política e Direito (UnB).

alexandrearcos@aunb.br

\section{Alexandre Douglas Zaidan de Carvalho}

Mestre em Direito pela Universidade Federal de Pernambuco e doutorando em Direito pela Universidade de

Brasília (UnB). Procurador federal. Pesquisador do Grupo de Pesquisa em Política e Direito (UnB).

douglas.zaidanagmail.com

Felipe Justino de Farias

Bacharel em DiReito pela Universidade de Brasília (UnB). SERVIDor da Coordenadoria de ANálise de JURISPRUdênCIA do STF. Pesquisador do Grupo de Pesquisa em Política e

DiReito (UnB).

felipe.justino.farias@gmail.com 